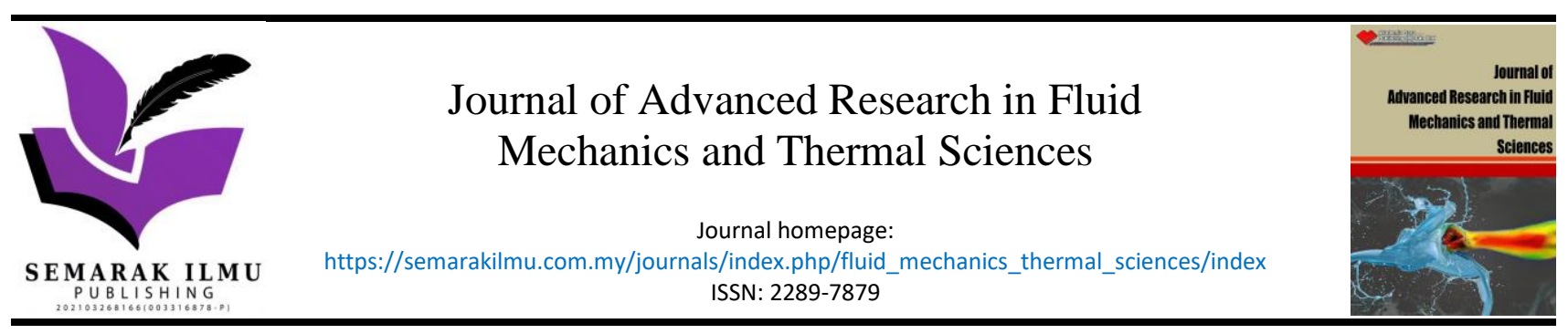

\title{
Effects of Minimum Quantity Lubrication Technique in Different Machining Processes - A Comprehensive Review
}

\author{
Wajiha Tasnim Urmi ${ }^{1,}{ }^{*}$, Md Mustafizur Rahman ${ }^{1,2, *}$, Wahaizad Safiei ${ }^{1}$, Kumaran Kadirgama ${ }^{2}$, Md \\ Abdul Maleque ${ }^{3}$ \\ Department of Mechanical Engineering, Faculty of Engineering, Universiti Malaysia Pahang, Lebuhraya Tun Razak, 26300 Gambang, Kuantan \\ Malaysia \\ 2 Automotive Engineering Centre, Universiti Malaysia Pahang, 26600 Pekan, Pahang, Malaysia \\ 3 Department of Manufacturing and Materials Engineering Faculty of Engineering, International Islamic University Malaysia, Jalan Gombak, 53100 \\ Kuala Lumpur, Malaysia
}

\section{ARTICLE INFO ABSTRACT}

\section{Article history:}

Received 7 August 2021

Received in revised form 5 December 2021

Accepted 20 December 2021

Available online 7 January 2022

\begin{abstract}
The cooling condition has a significant effect in the metal cutting industry, which has a crucial role in cooling and lubricating the workpiece-tool interface, reducing friction, and removing chips from the cutting area. Almost $15-20 \%$ of the overall machining cost was incurred from cooling and lubrication. So, the considerable cost can be occurred due to the supply, preparation, and disposal of cooling lubricants. Moreover, exposure to these substances can pollute the environment and hamper operators' health. Therefore, of late, researchers have been giving priority to investigate the effects of the Minimum Quantity Lubrication (MQL) techniques in machining as it alleviates the coolant usage by splashing fluid and compressed air mixtures. In this lubrication technique, the maximum fluid flow is less than $50 \mathrm{ml} / \mathrm{h}$, whereas flooded cooling technology uses up to 12,000 litres per hour. Most researchers found that a lower coefficient of friction, better surface finish, reduced cutting forces, and torques can be obtained using the MQL method in an optimized manner compared to dry and wet machining. Moreover, besides improving machinability characteristics, the MQL technique also complies with green and sustainable machining. Thus, a prospective solution to dry and wet processing. This paper represents the brief discussion and mechanism of the MQL technique and the effects of the MQL technique on the performance parameters of different machining processes.
\end{abstract}

\section{Introduction}

Machining is one of the leading manufacturing processes that substantially affect production costs. Machining efficiency is retarded by repeated tool change owing to wear [1]. The consequences of tool wear are low surface integrity, dimensional imprecision resulting in reduced product quality [2]. Besides environmental aspects in machining, the insistence for improved quality directs to

\footnotetext{
* Corresponding author.

E-mail address: urmee.ipe@gmail.com

- Corresponding author.

E-mail address: mustafizur@ump.edu.my
}

https://doi.org/10.37934/arfmts.90.2.135159 
superior machined surface integrity, which is directly linked to the product's function, reliability, and appearance. Maintaining a proper lubrication system in machining can enhance the machined surface properties. Moreover, friction is experienced with the elevated temperature at the contact zone of the tool and workpiece in the machining process. Among various cooling techniques, the conventional flooded cooling system is complex in maintenance, expensive to run, and hazardous to workers and work due to leakage and troublesome odor. Besides, the dry cutting condition cannot be applied everywhere for the cutting tool's limited capability. On the contrary, from different reviewed literature, it is found that the performance of MQL in various machining is sometimes mostly similar to and even in some cases superior to flooded cooling. Minimum Quantity Lubrication has already been established as a substitute to conventional lubrication systems for its increasing application in metal-cutting machining [3].

In a minimum quantity lubrication system, less lubrication and space are required, and there is no complexity in the treatment and disposal of the fluid, which can only be removed by a tissue [4]. Hence, it is also referred to as 'Near Dry Machining', where very little fluid is splashed at the toolworkpiece contact region [4-6]. Enhanced surface integrity and tool life, less cutting forces, and better process capability exert minimum quantity lubrication [7]. In the MQL system, the lubricant is applied directly at the contact surfaces tool, workpiece, and chip; a minimal amount of liquid is needed to reduce friction between workpiece and tool. The dosage of MQL quantity depends on the materials, tools, and machining process. The typical quantity supplied by MQL per process hour is 5 $\mathrm{ml}$ to $50 \mathrm{ml}$ [7]. Besides, the German DIN specification specifies the lubricant range up to $50 \mathrm{ml} / \mathrm{h}$ (1.7 $\mathrm{oz} / \mathrm{h})$, but $150 \mathrm{ml} / \mathrm{h}(5 \mathrm{oz} / \mathrm{h})$ in notable instances, whereas some references put the range up to 500 $\mathrm{ml} / \mathrm{h}(17 \mathrm{oz} / \mathrm{h})$. Generally, tools with less than $40 \mathrm{~mm}$ diameter need 5 to $80 \mathrm{ml} / \mathrm{h}$ of lubricant to give better results and keep chips dry whereas flood coolant typically uses $30,000-60,000 \mathrm{ml} / \mathrm{h}$ ( 8 to 16 gallon/hour) [8]. Moreover, the MQL can be regarded as an environmentally friendly process, and further focus on selection and characteristic of fluids in MQL can make it more sustainable for example if the fluid can be more potential, biodegradable etc.

Cost encountered in flood machining conditions (inventory, maintenance, preparation, disposal of chips and fluids) is much more than MQL costing. Literature found that almost $15-20 \%$ of the overall machining cost is incurred for coolants and lubricants in industries [9-12]. According to DeVries et al., [13] among total operation costs, 8-16\% of costing is related to metalworking fluids, and MQL significantly reduces these costs as in MQL, there is no cost for drying the chips and cleaning the workpiece and chips. MQL reduces cost and ensures a better workplace for employees by reducing health hazards from exposure to harmful and toxic fluids and air, leading to adverse health and safety conditions causing respiratory distress syndrome, eczema, and even cancer [7]. MQL has been reported by Banerjee and Sharma [14] as an improved technique than traditional flooded machining at higher speeds and feed rates, as it decreases the friction of the tool-workpiece interface considerably. Ismail et al., [15] stated that MQL shows better machining performance, and cutting oil film average thickness was not noticeably fluctuated with rising speed during milling machining under $\mathrm{MQL}$ conditions. The MQL machining with $\mathrm{SiO}_{2}-\mathrm{Al}_{2} \mathrm{O}_{3}-\mathrm{ZrO}_{2}$ nanofluid revealed lower cutting force during milling of Aluminum Alloy 6061-T6 due to the formation of the thin film of nanofluid on the tool-chip-workpiece interface [16]. Weinert et al., [17] reported that it adversely affects the workplace and worker health during the use and disposal of liquid. Still, complete elimination of coolants is difficult as dry machining drastically eliminates tool life $[18,19]$. Sreejith and Ngoi [19] also suggested avoiding excessive use of cutting fluids. Lawal et al., [5] investigated and compared different cooling techniques and found superior performance for MQL conditions. German Federal Ministry of Education and Research accomplished a three years project named "Forschung für die Produktion von Morgen" or "Research for Tomorrow's Production" where numerous companies' 
involvement ensured the completion of fifty-eight studies using many different materials under MQL condition [8]. Table 1 presents the effects of MQL in specific conditions. Many researchers investigated focusing effects of various parameters on available cooling and lubricating techniques using conventional fluids. In this study, different parameters on the MQL system are reviewed, including the mechanism of MQL, challenges, and opportunities of this method.

Table 1

Effects of MQL in different businesses [6]

\begin{tabular}{|c|c|c|c|c|}
\hline Business & Product & Material & Process & Results \\
\hline Automotive Supplier & $\begin{array}{l}\text { Throttle } \\
\text { Housings }\end{array}$ & GD-AISi1 ${ }_{2} \mathrm{Cu}_{4}$ & $\begin{array}{l}\text { Milling, Drilling, } \\
\text { Reaming }\end{array}$ & $8 \%$ component cost reduced. \\
\hline $\begin{array}{l}\text { Automotive } \\
\text { Manufacturer }\end{array}$ & $\begin{array}{l}\text { Gears, Car } \\
\text { Gearboxes }\end{array}$ & $\begin{array}{l}\text { Case- } \\
\text { hardened steel } \\
\left(20 \mathrm{MoCr}_{4}\right)\end{array}$ & Shaping & $\begin{array}{l}5 \% \text { component costs reduced } \\
\text { and environmental protection. }\end{array}$ \\
\hline $\begin{array}{l}\text { Power Plant } \\
\text { Manufacturers }\end{array}$ & Turbine Blades & $\begin{array}{l}\text { X22CrMoV 12.1, } \\
\text { CrNi Steels }\end{array}$ & Milling & Three folds enhance tool life. \\
\hline $\begin{array}{l}\text { Pneumatic Cylinders } \\
\text { Manufacturer }\end{array}$ & Connector & $\begin{array}{l}\text { A1 Die-Cast GD- } \\
\text { ZnA14Cul }\end{array}$ & $\begin{array}{l}\text { Tapping, } \\
\text { Grooving }\end{array}$ & $\begin{array}{l}\text { Less usage of metalworking } \\
\text { fluids, easy maintenance and job } \\
\text { cleaning, cleaner machine } \\
\text { environment. }\end{array}$ \\
\hline Die and Tool Shop & Tools & Tool Steels & Milling, Turning & $\begin{array}{l}\text { Maintenance and cleaning work } \\
\text { reduced by } 80 \% \text {, more efficient } \\
\text { processing time and better } \\
\text { surface finish. }\end{array}$ \\
\hline $\begin{array}{l}\text { Commercial } \\
\text { Printing Press } \\
\text { Manufacturer }\end{array}$ & $\begin{array}{l}\text { Drilled And } \\
\text { Tapped Strips }\end{array}$ & Ck45 & $\begin{array}{l}\text { Milling, Drilling, } \\
\text { Threading, } \\
\text { Reaming }\end{array}$ & $\begin{array}{l}\text { Shortened the processing time } \\
\text { from } 10.49 \mathrm{~min} \text { to } 7.32 \mathrm{~min} \text {. }\end{array}$ \\
\hline Aviation & $\begin{array}{l}\text { Aircraft } \\
\text { Components }\end{array}$ & AL Forged Alloy & Milling & $\begin{array}{l}\text { Cleaner machine environment, } \\
\text { environmental protection. }\end{array}$ \\
\hline
\end{tabular}

\section{Mechanism of MQL System}

In the MQL technique, the aerosol is formed by mixing a minimal amount of lubricant, and a nozzle is used to splash in the cutting zone at high pressure [20]. MQL system consists of four main components, e.g., machine, tooling, applicator, and output [8]. The applicator defines the quantity of air and fluid to be supplied; output presents the fluid chambers, hoses, and nozzles where the fluid comes across the atmosphere, and the tooling includes tool and tool holder. In a word, an automizer, fluid reservoir, and nozzles consist of the MQL system. The principal purpose of the MQL system is to supply the cutting area with a suitable lubricant [7]. MQL can be classified into two types depending on the cutting fluid supply mode, such as internal and external supply systems. These techniques are also called internal and external delivery or feed system [21]. The aerosol is synthesized in the atomizer in the external system, an ejector for atomizing the coolant at high-pressure air, and sprayed to the tool's outer surface with an external nozzle. This system applies to open machines, intermittent cutting operations, and machines with no internal coolant system [8]. Although external nozzles are associated with low cost and simple installation, manual adjustment and positioning are needed for nozzles. Moreover, the internal system is deployed where the cutting interfaces are not easily accessible in some situations.

On the contrary, the internal system allows the lubricant to be directly supplied to the cutting area using the tool's internal cooling channels with no feed nozzles adjustment [7]. Internal feed systems can be of two types, e.g., single-channel devices and dual-channel devices. Under this 
system, lubrication and cooling purpose are served by cutting fluid and pressurized air, respectively. Using the internal feed system, optimum lubrication for the cutting zone is possible with no spray losses, but special tools, machines, and high investment are needed. In the MQL system, single and dual channels are usually used for feeding input, e.g., air and oil. The main difference between these two is single-channel system allows the preparation of aerosol in the applicator before the spindle, but in a dual channel system separate channel is used to feed air and oil and come across together while exiting the spindle or in the tool holder so to generate aerosol directly in front of the tool [8].

Several experiments have been accomplished to investigate the performance of MQL in machining. Better surface integrity, prolonged tool life can be achieved near micro-milling using MQL conditions [22]. Also, for micro grinding Li and Lin [22] observed better surface integrity and improved tool life using MQL. Hadad and Sadeghi [23] found enhanced turning performance by using the MQL condition. MQL significantly increased tool life, reduce torque and thrust force while using nanodiamond-based nanofluid (NF) [24]. Shen et al., [25] found that the MQL method with $\mathrm{MoS}_{2}$ nanoparticles reduces force and friction because the inclusion of nanoparticles shows significant improvement of thermal conductivity, which plays a role in better heat transfer into the cutting zone during machining [26-28]. MQL with $\mathrm{Al}_{2} \mathrm{O}_{3}$ and diamond nanofluids reduce the machined surface forces and roughness and prevent burning the workpiece using water as a base liquid [29]. Improved tool life and workpiece surface are achieved during Inconel-718 using the MQL technique compared to dry and flooded machining [30]. Moreover, a new method was also investigated, termed a combined cooling technique. In this method, the pre-cooled workpiece is incorporated with a cutting fluid under the MQL technique, and it showed substantial improvement to machining performance, ensuring ecological and health issues [31].

\section{MQL in Different Machining}

In machining, MQL has become an efficient solution to reduce the excessive use of cutting liquids and maintaining environmental and health issues. This section will present the application of MQL and its effect on machining performance for different machining operations, such as turning, milling, and drilling.

\subsection{MQL in Turning}

Das et al., [32] carried out a study exploring surface roughness, tool wear, chip tectonic using carbide inserts coated with physical vapor deposition multilayer (MT PVD) Al2O3 external layer has a significance of CNMG120408. This study conducted the turning process of heat-treated AISI4340 ( $50 \pm 1 \mathrm{HRC}$ ). In tool wear, flank shows the maximum value of $0.3 \mathrm{~mm}$ wear even at higher speed for both dry and MQL machining while using multi-layered coated carbide insert; abrasion and diffusion predominate tool wear cutting edge, there is no chipping and catastrophic failure. Flank wear predominates with the increasing speed, and MQL exhibits a lesser amount of tool wear than dry machining. The color of the chip remains metallic even at higher speed and feed while lubricant is used, but the blue, burnt color chip is generated while machining without lubricant. The maximum surface roughness value does not surpass 1.6 microns even at a higher feed rate while using a multilayered carbide insert. Surface roughness enhances with the growing feed rate, and MQL shows a reduced amount of surface roughness.

Patole and Kulkarni [33] conducted experiments to optimize process parameters during the turning of AISI4340. Here, the operation was done using a tungsten carbide insert (specification CCMT- 090308) under MQL condition, including 0.20 wt\% multi-walled carbon nanotube (MWCNT) 
nanofluid. Experimental results show that the feed rate is the most influential parameter for achieving minimum surface roughness, whereas cutting speed is the least significant, and depth of cut has a moderate effect on surface roughness. So, they concluded that MQL with nanofluid is an alternative to the conventional flood coolant system. Thus, it is sure to obtain better surface integrity, prolonged tool life through controlling temperature and cutting forces at a rational level. During turning of St 52-3 under minimum quantity lubrication system, $17 \%$ less cutting force is required while there is no significant influence of nozzle position on cutting forces [34]. This study proved that a substantial amount of energy savings with sustainable manufacturing is possible through MQL machining, while the suitable oil flow rate was $10 \mathrm{ml} / \mathrm{h}$ [34]. Joshi [35] made an experiment performing turning of Incoloy 800 under dry, MQL (MQL1-150ml/h, MQL2-230 ml/h), flooded condition, and made a comparison for proper cutting parameters. The results show that under MQL2 condition, tool wear and surface roughness have occurred less than dry, flooded, and even with MQL1. They found that with the enhancement of speed, wear at flank face shows positive growth, so they concluded speed as the most dominant factor followed by feed, depth of cut and also found highest surface roughness at dry turning condition for highest feed and speed, lowest surface roughness at MQL2 machining condition.

During turning of steel alloy (EN 353) using uncoated CNMG carbide tools, chemical vapor deposition (CVD) and PVD coated inserts under dry, MQL, flooded condition Vishnu et al., [36] found optimum condition for minimizing cutting temperature. In this investigation, the optimum machining condition demonstrates with $1100 \mathrm{rpm}$ cutting speed, $0.5 \mathrm{~mm}$ and $0.2 \mathrm{~mm} / \mathrm{rev}$ depth of cut and feed rate, respectively, along with PVD coated tool. Flooded machining shows better performance than MQL condition, but little difference between them, whereas MQL reduces lubricants' flow considerably compared with the flooded condition. So, they concluded that MQL machining is more suitable than the dry and flooded state in terms of cost, sustainability, and health issues. From their experiment, significant intercommunication between lubrication type with tool type, cutting speed, depth of cut, and feed rate are explored. Under dry machining condition, stable machining condition was achieved with no catastrophic failure, plastic deformation on the cutting edge; and maximum flank wear is $0.3 \mathrm{~mm}$, whereas MQL shows lesser flank wear than dry condition and flank wear encountered for abrasion [37]. Cutting speed predominates flank surface, and surface roughness is influenced by feed derived from this experiment. They also suggested that in comparison with MQL, chipping failure is more dominant in dry machining.

Coolant system influences over the material adhesion eminently and highest adhesion encountered on the flank and rake clearance faces of the tool during dry machining whereas cooling condition has a less substantial impact on tool flank wear. It is reported by Sreejith [38] in turning aluminum 6061 alloys using diamond layered carbide tool under dry, MQL, and flooded conditions. Cutting forces also showed the highest value under dry conditions because of workpiece adhesion on the tool, and for flooded condition, cutting force showed the lowest value for minimum adhesion on the tool, and surface roughness value shows enhancement while increasing cutting speed (400 $\mathrm{m} / \mathrm{min}$ ). Finally, better surface integrity is achieved from MQL machining than dry and wet machining [38]. Sivaiah and Chakradhar [39] investigated the performance of cryogenic coolant on stainless steel (17-4 PH) machining. From this experiment, flank and rake surface wear, surface roughness, cutting temperature is observed for the rising depth of cut under dry, wet, cryogenic and MQL machining condition. The results reveal that cryogenic machining displays improved efficiency for surface finishing, wear of the tool, chip morphology relative to other machining circumstances, and produces less thick chips. This machining also enhances productivity as this condition is health and environment-friendly. 
Marques et al., [40] experimented with assessing solid lubricant performance into the vegetablebased oil applied by MQL during the turning process of Inconel 718 with ceramic tools $\left(\mathrm{Al}_{2} \mathrm{O}_{3}+\mathrm{SiCW}\right)$ is whisker reinforced. The results showed that LB 2000 with graphite and without solid lubricants led to a shorter lifetime of the tool than dry machining. Besides, the use of $\mathrm{MoS}_{2}$ as a solid lubricant with the inclusion of base oil into the cutting zone exhibited $12 \%$ and $46 \%$ enhancement of tool life than dry and MQL techniques, respectively. Machining with the MQL technique presented lower cutting forces than dry machining, while cutting forces show a slight increment with rising cutting speed. For a solid lubricant, the cutting force is reduced for both (graphite, $\operatorname{MoS}_{2 \text { ); }}$ sometimes, graphite shows better performance depending on the cutting speed. Moreover, for increasing speed, surface integrity also shows better performance. The notch, flank, and small crater were observed as dominant tool wear and adhesion and abrasion as significant wear mechanisms. However, Abd Rahim and Dorairaju [41] explored the MQL technique's performance under various spray and machining conditions. In their experiment, lubricant spray's characterization is done through Phase Doppler Anemometry for two different diameters nozzles $(2.5 \mathrm{~mm}$ and $3.0 \mathrm{~mm})$ at various input pressure. The investigation revealed the largest spray cone angle as the most effective splash pattern under 0.4 MPa air pressure as they found that with the enhancement of air pressure, the splash angle becomes wider for both diameters nozzles. They also recommended 6-9mm nozzle space for $3.0 \mathrm{~mm}$ diameter nozzle at 0.4 MPa while cutting force and temperature reduced remarkably.

The chip-tool interface temperature is enhanced consistently with growing cutting speed. However, other cutting conditions, such as depth of cut, have comparatively less effect on the chiptool interaction temperature during the investigation of the chip-tool interaction parameters and cutting condition while turning AISI1060 using TiCN coated cemented carbide SNMG 120, 408 insert [42]. In this investigation, important parameters were cutting speed, depth of cut, feed, temperature, shear angle, chip compression ratio, and friction coefficient. The study reveals that though the MQL system reduces the chip tool interface temperature significantly but has a low impact on friction and chip formation issues. The study is significant for exploring the suitable MQL condition, including optimized shear angle, coefficient of friction, chip compression ratio for $90 \mathrm{~m} / \mathrm{min}$ cutting speed, $0.1 \mathrm{~mm}$ feed, and $1.5 \mathrm{~mm}$ depth of cut simultaneously. Behera et al., [43] performed turning operations for Nimonic 90 and TiAl4V to assess the wear behavior of PVD TiN layered carbide inserts under MQL and dry machining. In the case of machining of Nimonic 90, severe wear of nose over cutting inserts was encountered due to chip tool high contact, and at the same time, eminent strength of Nimonic 90 is responsible for high notch wear. On the contrary for turning of TiAl4V under MQL conditions, better results were derived from the experiment. In this case, a reduction of flank wear and rake wear occurred for good wettability and high penetration characteristics, and this controlled wear, stable, and comparatively low cutting force is required for machining of TiAl4V. Table 2 and Table 3 summarize detailed information of machining parameters, lubrication mode, cutting fluid for turning operation. However, Table 4 presents the experimental results of different lubrication systems for turning various workpieces. 
Table 2

Summary of various machining parameters for turning operation

\begin{tabular}{|c|c|c|c|c|c|c|}
\hline References & $\begin{array}{l}\text { Workpiece } \\
\text { material and } \\
\text { geometry }(\mathrm{mm})\end{array}$ & $\begin{array}{l}\text { Cutting tool } \\
\text { material }\end{array}$ & Tool geometry & $\begin{array}{l}\text { Cutting } \\
\text { speed }\end{array}$ & Feed & Depth of cut \\
\hline $\begin{array}{l}\text { Patole and } \\
\text { Kulkarni } \\
{[33]}\end{array}$ & $\begin{array}{l}\text { AISI4340 } \\
\text { (Dia } 24 \text { and L 100) }\end{array}$ & $\begin{array}{l}\text { tungsten coated } \\
\text { CCMT- } \\
\text { 090308) }\end{array}$ & $\begin{array}{l}\text { Nose radius } 0.4 \text {, } \\
0.8 \mathrm{~m}\end{array}$ & 75,90 & $\begin{array}{l}0.04- \\
0.12\end{array}$ & $0.5,1,1.5$ \\
\hline $\begin{array}{l}\text { Ekinovic et } \\
\text { al., [34] }\end{array}$ & $\begin{array}{l}\text { St52-3; tensile } \\
\text { strength } 500 \mathrm{MPa} \text {, } \\
\text { hardness } 160 \mathrm{HB}\end{array}$ & $\begin{array}{l}\text { cemented } \\
\text { carbide (ISO } 1 \text { R } \\
3232 \text { K10) }\end{array}$ & & 95 & 0.142 & 1.0 \\
\hline Joshi [35] & $\begin{array}{l}\text { Incoloy } 800 \text { (Dia } \\
32 \text { and L 200) }\end{array}$ & $\begin{array}{l}\text { Uncoated } \\
\text { tungsten carbide }\end{array}$ & CNMG120408 & $\begin{array}{l}40,50 \text { and } \\
60\end{array}$ & $\begin{array}{l}0.033 \\
0.066 \\
0.132\end{array}$ & $\begin{array}{l}0.5,0.75 \\
\text { and } 1.0\end{array}$ \\
\hline $\begin{array}{l}\text { Vishnu et } \\
\text { al., [36] }\end{array}$ & $\begin{array}{l}\text { EN } 353 \text { Steel } \\
\text { Alloys }\end{array}$ & $\begin{array}{l}\text { Uncoated, CVD, } \\
\text { PVD coated } \\
\text { CNMG carbide } \\
\text { tools }\end{array}$ & & $\begin{array}{l}700,1100 \\
1500 \mathrm{rpm}\end{array}$ & $\begin{array}{l}0.2,0.5 \\
0.8\end{array}$ & $0.5,1.5,2.5$ \\
\hline $\begin{array}{l}\text { Das et al., } \\
{[32]}\end{array}$ & $\begin{array}{l}\text { AISI4340; } 50 \pm 1 \\
\text { HRC; } \\
\text { (Dia } 40 \text { and L 18) }\end{array}$ & $\begin{array}{l}\text { MT PVD coated } \\
\text { carbide insert } \\
\text { with } \mathrm{Al}_{2} \mathrm{O}_{3} \\
\text { external layer }\end{array}$ & CNMG120408 & $\begin{array}{l}50,100 \\
150,200\end{array}$ & $\begin{array}{l}0.04 \\
0.08 \\
0.12 \\
0.16\end{array}$ & 0.2 \\
\hline $\begin{array}{l}\text { Das et al., } \\
{[37]}\end{array}$ & $\begin{array}{l}\text { AISI4340; } 50 \pm 1 \\
\text { HRC; Dia } 40 \text { and L } \\
\text { 180) }\end{array}$ & $\begin{array}{l}\text { MT CVD } \\
\text { multilayer } \\
\text { coated carbide } \\
\text { tool with an } \\
\text { external TiN } \\
\text { layer }\end{array}$ & CNMG120408 & $\begin{array}{l}50,100 \\
150,200\end{array}$ & $\begin{array}{l}0.04 \\
0.08 \\
0.12 \\
0.16\end{array}$ & \\
\hline Sreejith [38] & $\begin{array}{l}6061 \text { aluminum } \\
\text { alloy }\end{array}$ & $\begin{array}{l}\text { diamond-coated } \\
\text { inserts CNGA } \\
120408 \\
\text { T01020 WG }\end{array}$ & $\begin{array}{l}\text { rake and } \\
\text { clearance angle } \\
15^{\circ}, 7^{\circ} ; \text { nose } \\
\text { radius } 0.8 \mathrm{~mm}\end{array}$ & 50 up to 400 & 0.15 & 1.0 \\
\hline $\begin{array}{l}\text { Marques et } \\
\text { al., [40] }\end{array}$ & $\begin{array}{l}\text { Nickel base super } \\
\text { alloys; } 40 \mathrm{HRC} ; \varnothing \\
127 \times 250 \mathrm{~mm} \\
\text { length }\end{array}$ & $\begin{array}{l}\text { SNGN } 120712 \\
\text { T01020, grade } \\
\text { CC670 }\end{array}$ & $\begin{array}{l}\text { nose radius } \\
1.2 \mathrm{~mm} \text {, tool } \\
\text { holder- CSRNR } \\
2525 \mathrm{M} 12-4\end{array}$ & $\begin{array}{l}100,150 \\
200,250 \\
300\end{array}$ & 0.1 & 0.5 \\
\hline $\begin{array}{l}\text { Abd Rahim } \\
\text { and }\end{array}$ & $\begin{array}{l}\text { AISI1045 medium } \\
\text { carbon steel; Dia }\end{array}$ & $\begin{array}{l}\text { Cemented } \\
\text { carbide }\end{array}$ & & $\begin{array}{l}100,160 \\
220\end{array}$ & $\begin{array}{l}0.15 \\
0.30\end{array}$ & 0.2 \\
\hline $\begin{array}{l}\text { Dorairaju } \\
\text { [41] }\end{array}$ & 100 and L 200) & $\begin{array}{l}\text { TNGG220408R } \\
\text { insert }\end{array}$ & & & & \\
\hline $\begin{array}{l}\text { Mia et al., } \\
{[42]}\end{array}$ & $\begin{array}{l}\text { AISI1060; dia. } 47.5 \\
\mathrm{~mm}, \mathrm{~L} 200 \mathrm{~mm}\end{array}$ & $\begin{array}{l}\text { SNMG 120,408 } \\
\text { insert; TiCN } \\
\text { coated } \\
\text { cemented } \\
\text { carbide }\end{array}$ & $\begin{array}{l}\text { Rake } \& \text { cutting } \\
\text { angle } 0^{\circ}, 90^{\circ} ; \\
\text { nose radius } \\
0.8 \mathrm{~mm}\end{array}$ & $45,60,75,90$ & $\begin{array}{l}0.10 \\
0.20\end{array}$ & $1.0,1.5$ \\
\hline $\begin{array}{l}\text { Behera et } \\
\text { al., [43] }\end{array}$ & $\begin{array}{l}\text { Nimonic } 90 \text { (Dia } \\
60 \text { and L 300), } \\
\text { Ti6Al4V (Dia } 50 \\
\text { and L 300) }\end{array}$ & $\begin{array}{l}\text { KC730- } \\
\text { Kennameta }\end{array}$ & & 60,120 & $\begin{array}{l}0.15 \\
0.25\end{array}$ & 0.5 \\
\hline $\begin{array}{l}\text { Sivaiah and } \\
\text { Chakradhar } \\
\text { [39] }\end{array}$ & $\begin{array}{l}\text { 17-4 PH SS bar } \\
\text { (Dia } 50 \text { and L 300) }\end{array}$ & $\begin{array}{l}\text { AlTiN PVD } \\
\text { coated KC5010 } \\
\text { WC inserts; } \\
\text { SNMG120408 } \\
\text { MP }\end{array}$ & $\begin{array}{l}\text { cutting edge } \\
\text { angle } 75^{\circ} . \text { nose } \\
\text { radius: } 0.8 \mathrm{~mm}\end{array}$ & 78.5 & 0.143 & $\begin{array}{l}0.2,0.4,0.6, \\
0.8 \text { and } 1\end{array}$ \\
\hline
\end{tabular}


Table 3

Summary of lubrication mode, cutting fluids, other specifications of various coolant systems for turning

\begin{tabular}{|c|c|c|c|c|c|c|}
\hline References & $\begin{array}{l}\text { Mode of } \\
\text { Lubrication }\end{array}$ & Cutting fluid & $\begin{array}{l}\text { MQL flow rate } \\
(\mathrm{ml} / \mathrm{h})\end{array}$ & $\begin{array}{l}\text { MQL Air } \\
\text { and Fluid } \\
\text { Pressure }\end{array}$ & $\begin{array}{l}\text { Nanoparticles, } \\
\text { wt\%, Spray } \\
\text { angle }\end{array}$ & $\begin{array}{l}\text { Other coolant } \\
\text { Specifications }\end{array}$ \\
\hline $\begin{array}{l}\text { Patole and } \\
\text { Kulkarni [33] }\end{array}$ & MQL, Flood & $\begin{array}{l}\text { Ethylene } \\
\text { glycol }\end{array}$ & 140 & 5 bar (air) & $\begin{array}{l}\text { MWCNT, } \\
0.20 \%, 30^{\circ}\end{array}$ & $\begin{array}{l}\text { distance } \\
\text { between nozzle } \\
\& \text { insert tip } 11 \\
\text { mm }\end{array}$ \\
\hline $\begin{array}{l}\text { Ekinovic et } \\
\text { al., [34] }\end{array}$ & MQL & $\begin{array}{l}\text { Biodegradable } \\
\text { rapeseed oil }\end{array}$ & $\begin{array}{l}10 \text { to } 50 \text { (oil), } \\
0.3 \text { to } 1700 \mathrm{ml} / \mathrm{h} \\
\text { (water) }\end{array}$ & & & \\
\hline $\begin{array}{l}\text { Joshi et al., } \\
\text { [35] }\end{array}$ & $\begin{array}{l}\text { Dry, MQL, } \\
\text { Flood }\end{array}$ & & $\begin{array}{l}\text { MQL1 (150), } \\
\text { MQL2 (230); } \\
\text { Flood- } 600\end{array}$ & & & \\
\hline $\begin{array}{l}\text { Vishnu et al., } \\
\text { [36] }\end{array}$ & $\begin{array}{l}\text { MQL, } \\
\text { Flooded, Dry }\end{array}$ & Water & 85 & 1bar(air) & $\mathrm{Al}_{2} \mathrm{O}_{3}$ & \\
\hline $\begin{array}{l}\text { Das et al., } \\
\text { [32] }\end{array}$ & Dry, MQL & & 50 & $\begin{array}{l}\text { Oil-air mix. } \\
5 \text { bar }\end{array}$ & & \\
\hline $\begin{array}{l}\text { Das et al., } \\
{[37]}\end{array}$ & Dry, MQL & & 50 & 5 bar & & \\
\hline Sreejith [38] & $\begin{array}{l}\text { Gravity-fed } \\
\text { MQL } \\
\text { system, Dry, } \\
\text { Flood }\end{array}$ & $\begin{array}{l}\text { BP } \\
\text { Microtrend } \\
231 \mathrm{~L}\end{array}$ & 50 and 100 & & & \\
\hline $\begin{array}{l}\text { Marques et } \\
\text { al., [40] }\end{array}$ & Dry, MQL & $\begin{array}{l}\text { Accu-Lube LB } \\
2000\end{array}$ & 40 & $0.5 \mathrm{MPa}$ & $\begin{array}{l}\text { Graphite and } \\
\mathrm{MoS}_{2}\end{array}$ & $\begin{array}{l}\text { Nozzle distance } \\
\text { from cutting } \\
\text { zone } 30 \mathrm{~mm}\end{array}$ \\
\hline $\begin{array}{l}\text { Abd Rahim } \\
\text { and } \\
\text { Dorairaju } \\
\text { [41] }\end{array}$ & MQL & & & $\begin{array}{l}\text { Air pressure } \\
0.2,0.3,0.4 \\
\mathrm{MPa}\end{array}$ & & $\begin{array}{l}\text { Nozzle dia. } 2.5 \text {, } \\
3.0 \mathrm{~mm} \text {; } \\
\text { Nozzle space } 3 \text {, } \\
6,7,9 \mathrm{~mm}\end{array}$ \\
\hline $\begin{array}{l}\text { Mia et al., } \\
{[42]}\end{array}$ & Dry, MQL & Olive Oil & 150(oil) & 4 bar & & $\begin{array}{l}1.0 \mathrm{~mm} \\
\text { diameter nozzle }\end{array}$ \\
\hline $\begin{array}{l}\text { Behera et } \\
\text { al., [43] }\end{array}$ & Dry, MQL & $\begin{array}{l}\text { Sunflower oil } \\
\text { in water } \\
\text { (emulsion) }\end{array}$ & $250 \mathrm{ml} / \mathrm{h}$ & $\begin{array}{l}\text { Air pressure } \\
3 \text { bar }\end{array}$ & & $\begin{array}{l}\text { Spray velocity } \\
10-11 \mathrm{~m} / \mathrm{s}\end{array}$ \\
\hline $\begin{array}{l}\text { Sivaiah and } \\
\text { Chakradhar } \\
{[39]}\end{array}$ & $\begin{array}{l}\text { Dry, wet, } \\
\text { MQL, } \\
\text { Cryogenic } \\
\text { (LN2) }\end{array}$ & & $\begin{array}{l}\text { MQL- 70; } \\
\text { (Cryogenic-0.45 } \\
\text { kg/min; } \\
\text { Flood- } 6000 \\
\mathrm{ml} / \mathrm{min}\end{array}$ & $\begin{array}{l}\text { Compressed } \\
\text { air pressure } \\
4 \text { bar }\end{array}$ & & $\begin{array}{l}\text { Nozzle } \\
\text { diameters: } 1 \mathrm{~mm} \\
\text { (Cryogenic, } \\
\text { MQL), } 10 \mathrm{~mm} \\
\text { (wet) }\end{array}$ \\
\hline
\end{tabular}


Table 4

Summary of experimental results of different lubrication systems for turning of various workpieces

\begin{tabular}{|c|c|c|c|}
\hline Authors & $\begin{array}{l}\text { Workpiece } \\
\text { Material }\end{array}$ & $\begin{array}{l}\text { Mode of } \\
\text { Lubricant }\end{array}$ & Findings \\
\hline $\begin{array}{l}\text { Patole and } \\
\text { Kulkarni [33] }\end{array}$ & AISI4340 & MQL, Flood & $\begin{array}{l}\text { MQL with NF is a substitute for the traditional wet } \\
\text { cooling condition for improved surface integrity and } \\
\text { prolonged tool life. }\end{array}$ \\
\hline $\begin{array}{l}\text { Ekinovic et al., } \\
\text { [34] }\end{array}$ & St52-3 & $\begin{array}{l}\text { MQL (oil-in- } \\
\text { water droplet } \\
\text { system) }\end{array}$ & $17 \%$ less cutting force is required for MQL machining. \\
\hline Joshi [35] & Incoloy 800 & Dry, MQL, Flood & $\begin{array}{l}\text { MQL2 ( } 230 \mathrm{ml} / \mathrm{h}) \text { condition, tool wear, and surface } \\
\text { roughness intensity are less than dry, flooded, and even } \\
\text { MQL1 ( } 150 \mathrm{ml} / \mathrm{h}) \text {. } \\
\text { The dry turning condition gives the highest surface } \\
\text { roughness for the highest speed and feed combination, } \\
\text { and MQL2 gives the lowest surface roughness. }\end{array}$ \\
\hline $\begin{array}{l}\text { Vishnu et al., } \\
\text { [36] }\end{array}$ & $\begin{array}{l}\text { EN } 353 \text { Steel } \\
\text { Alloys }\end{array}$ & $\begin{array}{l}\text { MQL, Flooded, } \\
\text { Dry }\end{array}$ & $\begin{array}{l}\text { MQL machining is better than dry and flood conditions in } \\
\text { cost, ecology, and human health issues. }\end{array}$ \\
\hline Das et al., [32] & AISI 4340 & Dry, MQL & $\begin{array}{l}\text { Flank wear increases with the rising speed. MQL shows a } \\
\text { lesser amount of wear of the tool than dry condition } \\
\text { machining. }\end{array}$ \\
\hline Das et al., [37] & AISI 4340 & Dry, MQL & $\begin{array}{l}\text { MQL shows a lesser amount of flank wear. Cutting speed } \\
\text { predominates flank face wear, whereas surface integrity } \\
\text { is influenced mainly by feed rate. }\end{array}$ \\
\hline Sreejith [38] & $\begin{array}{l}6061 \text { aluminum } \\
\text { alloy }\end{array}$ & $\begin{array}{l}\text { Gravity-fed MQL } \\
\text { system, Dry, } \\
\text { Flood }\end{array}$ & $\begin{array}{l}\text { Dry machining shows the highest cutting forces, and } \\
\text { flood shows the least. MQL displays a reduction of } \\
\text { surface roughness than dry and flooded conditions. }\end{array}$ \\
\hline $\begin{array}{l}\text { Marques et al., } \\
{[40]}\end{array}$ & $\begin{array}{l}\text { Nickel-based } \\
\text { superalloys }\end{array}$ & Dry, MQL & $\begin{array}{l}12 \% \text { and } 46 \% \text { tool life enhancement are possible using } \\
\text { MoS } 2 \text { with base oil into the cutting zone compared to dry } \\
\text { and MQL machining. }\end{array}$ \\
\hline $\begin{array}{l}\text { Abd Rahim and } \\
\text { Dorairaju [41] }\end{array}$ & $\begin{array}{l}\text { AISI } 1045 \\
\text { medium carbon } \\
\text { steel }\end{array}$ & MQL & $\begin{array}{l}\text { Cutting temperatures and forces are reduced remarkably } \\
\text { for } 6-9 \mathrm{~mm} \text { nozzle space at } 0.4 \mathrm{MPa} \text {. }\end{array}$ \\
\hline Mia et al., [42] & AISI1060 steel & Dry, MQL & $\begin{array}{l}\text { MQL condition reduces the temperature of the chip-tool } \\
\text { contact region significantly, but this system has very few } \\
\text { impacts on friction and chip formation issues. }\end{array}$ \\
\hline $\begin{array}{l}\text { Behera et al., } \\
{[43]}\end{array}$ & $\begin{array}{l}\text { Nimonic 90; } \\
\text { TiAl4V }\end{array}$ & Dry, MQL & $\begin{array}{l}\text { Minimum flank wear is derived from the MQL machining } \\
\text { of TiAl4V for good wettability. }\end{array}$ \\
\hline $\begin{array}{l}\text { Sivaiah and } \\
\text { Chakradhar [39] }\end{array}$ & 17-4 PH SS & $\begin{array}{l}\text { Dry, wet, MQL, } \\
\text { Cryogenic (LN2) }\end{array}$ & $\begin{array}{l}\text { Cryogenic machining shows better performance for } \\
\text { surface finishing, wear of the tool, chip morphology, and } \\
\text { thinner chips than dry and MQL machining. }\end{array}$ \\
\hline
\end{tabular}

\subsection{MQL in Drilling}

Biermann and lovkov [44] experimented to explore workpiece temperature directs to deformation and possible straightness accuracy of the borehole. In their experiment, they used MQL and high feed process guiding strategies for enhancing deep hole drilling. The high feed process shows better productivity and less heat in the workpiece during drilling. High-speed steel (HSS) drill bit was used to drill magnesium alloy UNS M11917 under dry and MQL machining conditions to identify the best tool and surface integrity for the aeronautical sector [45]. The results revealed that the minimum and maximum surface roughness value was in the range of established value ( 0.8 to $0.16 \mu \mathrm{m}$ ) for the aeronautical sector, which improved the rising cutting speed. Moreover, $0.13 \mu \mathrm{m}$ and $0.87 \mu \mathrm{m}$ were the lowest and highest surface roughness values, respectively. They found that point angles of $118^{\circ}$ and $135^{\circ}$ are responsible for achieving the minimum surface roughness for higher 
and lower speed tools, respectively. They also suggested the feed rate's significance on the surface roughness for various cutting speeds and concluded that a higher feed rate exerts minimum surface roughness for lower cutting speed. On the contrary, enhanced surface roughness was obtained at higher feed rates for higher cutting speed due to evacuation difficulties of generated long chips.

Kuzu et al., [46] reported that dry machining is more feasible and economical in terms of cost and energy than MQL and even dry with compressed air condition as the critical factor-chip evacuation that influences the drill life for specific cutting parameters. Drilling throughput was investigated for compacted graphite iron (CGI) under dry (EXP-I), dry with compressed air (EXP-II), MQL (EXP-III) conditions. EXP-II (3150 and 2969 holes) provides better tool life for better cooling and chip evacuation capability in tool life. In this experiment, spiral chip (SC- long; difficult to evacuate), triangular chip (TC- less significant; easy to evacuate), and rectangular chip (RC) were found in the SEM micrographs. The maximum TC (66 \%) ratio found in EXP-II, which results in better drill life, whereas $52 \%$ in EXP-I and 60\% in EXP- III. However, for all the experiments, almost the same cutting force and torque were identified. They concluded that the MQL provides better lubrication while producing long chips, which are difficult to evacuate and reduces tool life.

On the contrary, under dry conditions, drilling of magnesium alloy AM60 was associated with concise drill life due to the formation of build-up-edge (BUE) and magnesium adhesion [47]. On the other hand, they found stable drilling performance for fatty acid (FA) and mineral oil (MO) based MQL providing small chips, soothing hole surface, increased tool life, comparatively less, and uniform torque and force. Moreover, under MQL conditions, the workpiece's maximum temperature is comparable to flooded and much less than dry condition. In this experiment, for their selected higher temperature and feed rates, they suggested the MQL flow rates. The results revealed that there were not any notable differences for $10,20,30 \mathrm{ml} / \mathrm{h}$ flow rates while five $\mathrm{ml} / \mathrm{h}$ flow rate directs to higher torques. MQL lubricants with high viscosity and cooling capacity extend tool life; dry drilling accelerates tool wear significantly during an investigation of the effect of MQL and its supplying behavior on various HSS twist drills during drilling of $0.45 \%$ carbon-containing plain carbon steel [48]. Three types of MQL were under consideration, such as MQL using synthetic ester (SE) and additives (add), Synthetic ester, additives, and $20 \%$ alcohol, Oil-free synthetic lubricant (SL) with 40\% water. In addition, four types of twist drills were used in this study, such as uncoated HSS (type A), Uncoated Co-HSS (type B), TiN-coated Co-HSS (type C), TiAIN coated Co-HSS (type D). The TiAIN multi-layered coated drills performed better for dry drilling due to their high hot hardness than uncoated HSS, CoHSS, and even TiN coated drills. In the case of MQL supplying manner from continuous supply to discontinuous supply, they reported $98 \%$ (536 to 13 boreholes), 42\% (709 to 411), 27\% (966 to 709) tool life drop for type B, C, D tools respectively. Le Coz et al., [49] experimented with establishing a temperature measurement system for rotating cutting tools. An integrated thermocouple position is very close to the cutting edge during the drilling and milling of titanium aluminum alloy under MQL and dry conditions, respectively. They found that the maximum temperatures for drilling (MQL) and milling (Dry) are $160^{\circ}$ and $620{ }^{\circ} \mathrm{C}$ for a hole depth of $20 \mathrm{~mm}$ and cutting length of $500 \mathrm{~mm}$ and concluded that cutting condition, tool geometry, and tool coating affects tool mechanism. However, Tasdelen et al., [50] compared cutting torques and forces, surface roughness, tool wear under air, emulsion, and MQL (flow rates- 5, 15, $23 \mathrm{ml} / \mathrm{h}$ ) condition during short hole drilling using 880 D1900L25-03 Coro drill with GM 1040 inserts. MQL and air-assisted drilling showed reduced tool wear at the periphery and midst of the edge, whereas emulsion exerted maximum tool wear. The highest value of flank and crater wear, the lowest value of cutting force were derived from the emulsion technique. They also found maximum cutting force from air-assisted drilling and five $\mathrm{ml} / \mathrm{h}$ flow of MQL but the comparatively lower force from $15 \mathrm{ml} / \mathrm{h}$ and $23 \mathrm{ml} / \mathrm{h}$ flow of MQL. In addition, this study also revealed air-assisted drilling is responsible for the highest surface roughness. 
Minimizing friction at the contact region during hole drilling is hindered by the chips' upward motion along the flute surface. Micro-textured drill tool surfaces may address this obstacle. Niketh and Samuel [51] experimented with understanding the effect of non-textured, margin, and flute textured drill tools using dry, wet, and MQL systems. They found the margin textured tool the most efficient, which reduces thrust force 10-12 \%, 15-20 \%, 15-19 \% in dry, wet, and MQL conditions, respectively. Again, Girinon et al., [52] explored 316L austenitic stainless steel drilling under dry, internal and external coolant systems. The results showed that the dry condition is severe for temperature, forces, and chip tectonics. In this condition, generated high heat of final workpiece directs to tensile residual stresses whereas heat generation is lower for external condition and tensile stress is originated from only circumferential residual stresses and for internal condition, heat is carried away by coolant and residual stresses are compressive.

In the case of surface integrity, internal coolant gives the best results, and dry condition gives the worst condition showing the highest roughness, which leads to crack propagation and part breakage [53]. Amini et al., [53] investigated the optimization of surface roughness and thrust force in drilling AISI1045 steel under dry, MQL, ultrasonic vibration (UV), and combined UV-MQL system. From single objective optimization findings, it is evident that a $14 \%$ reduction of thrust force and $11 \%$ reduction of surface roughness is possible under UV drilling.

The experiment also found that $931 \mathrm{rpm}$ speed and $90 \mathrm{~mm} / \mathrm{min}$ feed is the optimum point for lowest thrust force and $954 \mathrm{rpm}$ speed and $110 \mathrm{~mm} / \mathrm{min}$ feed for lowest surface roughness regarding multi-objective optimization. The findings also showed that broken chips produced under UV and UV-MQL conditions leading to a reduction in friction and consequently force, and under UV-MQL drilling, better surface quality is generated for lower BUE on the drill bit. Bhowmick and Alpas [54] performed drilling of 319 grade Al-Si alloys under $\mathrm{H}_{2} \mathrm{O}-\mathrm{MQL}$ conditions. Hydrogenated $(\mathrm{H})$ and nonhydrogenated $(\mathrm{NH})$ diamond-like carbon (DLC) layered drills were used for this study. The results showed the best performance in both types of DLC layered drills by reducing drilling torque which is most comparable to flooded drilling performance. They also specified that under NH-DLC coating is preferable for drilling Al-Si than H-DLC coated drills because this coating showed lower thrust force, torque, and BUE. Besides, the $\mathrm{H}_{2} \mathrm{O}-\mathrm{MQL}$ condition exerts a minimum area of aluminum adhesion of for both tools.

Immediate tool failure found for HSS dry drilling and tapping, but considerable improvement exhibited for DLC coated HSS dry tapping due to low friction coefficient, which prevents high heat generation and BUE formation [47]. The authors found a similar type of average torque of flooded tapping in the $80 \mathrm{ml} / \mathrm{h}$ flow rate of the MQL condition. The results showed $55{ }^{\circ} \mathrm{C}$ temperature reduction for MQL condition, and sulfur and phosphorus-based additives significantly prevent aluminum adhesion. Bhowmick and Alpas [55] experimented with cast AZ91, a magnesium alloy, using NH-DLC HSS drills under dry, MQL, and flooded conditions. Initially, they experimented with $1000,1500,2000,2500 \mathrm{rpm}$ and $0.10,0.15,0.20$, and $0.25 \mathrm{~mm} / \mathrm{rev}$ but noticed higher average torque for higher speed and feed rate combinations. Finally, they conducted experiments at $2500 \mathrm{rpm}$ and $0.25 \mathrm{~mm} / \mathrm{rev}$. Under the dry condition, this study revealed the flank type wear with NH-DLC due to high-temperature generation accompanying coating degradation. Recrystallization of AZ91 surfaces was also experienced under dry conditions using both uncoated and NH-DLC HSS drills. On the other hand, enhanced life of $\mathrm{NH}-\mathrm{DLC}$ drills with reduced temperature, torque, and friction, comparable to flooded drilling conditions at 30,000 ml/h flow rate of mineral oil, was observed for $\mathrm{H}_{2} \mathrm{O}-\mathrm{MQL}$ drilling conditions $30 \mathrm{ml} / \mathrm{h}$.

Giasin and Ayvar-Soberanis [56] experimented with investigating the impact of dry, liquid nitrogen coolant, MQL condition, and other cutting parameters on drilling-related damage fiber metal laminates. They found that under LN2 condition, the depth of erosion in glass fiber holes is 
higher than MQL and dry drilling and borehole surface damage intensity is lower than MQL and dry drilling. This experiment proved that the generation of waste reduced by using MQL and cryogenic cooling. Though increased spindle speed gives a better surface finish, it demonstrates more waste and chip adhesion under MQL and LN2. Moreover, increased speed and feed worsen the borehole surface, such as erosion, interlayer burr, and surface delamination. Under MQL condition heat balance of the drilling process and the workpiece's temperature outline are represented by Biermann and lovkov [57]. Besides providing good machinability, they also mentioned that the production cost reduced through an environmentally friendly MQL system. Table 5 and Table 6 summarize detailed information of various machining parameters for the drilling operation, lubrication mode, cutting fluids, other specifications of various coolant systems. However, Table 7 presents the experimental results of different lubrication systems for drilling of various workpieces.

Table 5

Summary of various machining parameters for the drilling operation

\begin{tabular}{|c|c|c|c|c|c|c|}
\hline References & $\begin{array}{l}\text { Workpiece } \\
\text { material and } \\
\text { geometry }\end{array}$ & $\begin{array}{l}\text { Cutting tool } \\
\text { material }\end{array}$ & Tool geometry & Cutting speed & Feed & $\begin{array}{l}\text { Drilling } \\
\text { depth }\end{array}$ \\
\hline $\begin{array}{l}\text { Kuzu et al., } \\
{[58]}\end{array}$ & $\begin{array}{l}\text { CGI } \\
\text { (Dia } 20 \text { and L } \\
\text { 200) } \mathrm{mm}\end{array}$ & $\begin{array}{l}\text { Uncoated two- } \\
\text { flute carbide } \\
\text { drill }\end{array}$ & $\begin{array}{l}10 \mathrm{~mm} \text { dia; } \\
\text { helix, point, } \\
\text { chisel angle } 30^{\circ} \text {, } \\
118^{\circ}, 120^{\circ}\end{array}$ & $\begin{array}{l}\text { EXP. I- 25, EXP } \\
\text { II-50, EXP III- } 75\end{array}$ & $\begin{array}{l}\text { EXP | } 0.15, \text { EXP } \\
\|-0.15, \text { EXP |II- } \\
0.1\end{array}$ & \\
\hline $\begin{array}{l}\text { Chatha et } \\
\text { al., [59] }\end{array}$ & $\begin{array}{l}\text { Aluminium } \\
6063\end{array}$ & HSS Drill Tool & Drill bit $6 \mathrm{~mm}$ & 30 and 53.7 & 60 & 20 \\
\hline $\begin{array}{l}\text { Berzosa et } \\
\text { al., [45] }\end{array}$ & $\begin{array}{l}\text { Magnesium } \\
\text { alloy UNS } \\
\text { M11917; } \\
110 \times 62 \times 50 \\
\mathrm{~mm}\end{array}$ & $\begin{array}{l}\text { HSS Steel Twist } \\
\text { Drill; }\end{array}$ & $\begin{array}{l}\text { dia. } 6 \mathrm{~mm} \text {, flute } \\
\mathrm{L} 28 \mathrm{~mm} \text {, point } \\
\text { angles } 118^{\circ} \text {, } \\
135^{\circ}\end{array}$ & 40,60 & $0.05,0.2$ & \\
\hline $\begin{array}{l}\text { Kuzu et al., } \\
{[46]}\end{array}$ & $\begin{array}{l}\text { CGI-Compacted } \\
\text { Graphite Iron }\end{array}$ & $\begin{array}{l}5 \mu \mathrm{m} \text { multi- } \\
\text { coating (AICrN, } \\
\text { TiAIN/AICrTiN) }\end{array}$ & $\begin{array}{l}\text { Dia. } 4 \mathrm{~mm} \text {, } \\
135^{\circ} \text {-point } \\
\text { angle }\end{array}$ & $\begin{array}{l}7961 \text { rpm } \\
\text { (spindle); } 100 \\
\text { (drill) }\end{array}$ & $26.5 \mathrm{~mm} / \mathrm{s}$ & \\
\hline $\begin{array}{l}\text { Bhowmick } \\
\text { et al., [60] }\end{array}$ & $\begin{array}{l}\text { Magnesium } \\
\text { alloy AM60; } \\
60 \times 10.16 \times \\
7.62 \mathrm{~cm}^{3}\end{array}$ & HSS twist drills; & $\begin{array}{l}\text { Dia } 6.35 \pm 0.01 \\
\text { mm dia; HRC: } \\
64 \pm 2.50\end{array}$ & $\begin{array}{l}1000,1500,2000 \\
2500 \mathrm{rpm}\end{array}$ & $\begin{array}{l}0.10,0.15,0.20 \\
0.25 \mathrm{~mm} / \mathrm{rev}\end{array}$ & \\
\hline $\begin{array}{l}\text { Heinemann } \\
\text { et al., [48] }\end{array}$ & $\begin{array}{l}\text { Plain carbon } \\
\text { steel }(0.45 \% \\
\text { carbon); }\end{array}$ & $\begin{array}{l}\text { Uncoated HSS, } \\
\text { Co-HSS, TiN } \\
\text { coated Co-HSS- } \\
\text { TiN, TiAIN } \\
\text { coated Co-HSS. }\end{array}$ & $\begin{array}{l}\text { Straight shank, } \\
\text { dia. } 1.5 \mathrm{~mm} \text {, } \\
\text { helix, point } \\
\text { angle } 40^{\circ}, 130^{\circ}\end{array}$ & $26 \mathrm{~m} / \mathrm{min}$ & $0.26 \mathrm{~mm} / \mathrm{rev}$ & \\
\hline $\begin{array}{l}\text { Le Coz et } \\
\text { al., [49] }\end{array}$ & $\begin{array}{l}\text { Titanium alloy } \\
\text { Ti6Al4V }\end{array}$ & $\begin{array}{l}\text { Uncoated Twist } \\
\text { Drill }\end{array}$ & $\begin{array}{l}\text { Dia. and length } \\
10 \mathrm{~mm} \& \\
43 \mathrm{~mm} \text {; point, } \\
\text { helix angle: } \\
130^{\circ}, 15^{\circ}\end{array}$ & $\begin{array}{l}30 \text { and } 35 \mathrm{~m} \\
/ \mathrm{min}\end{array}$ & $\begin{array}{l}0.1 ; 0.12 ; 0.14 ; \\
0.16 \mathrm{~mm} / \mathrm{rev}\end{array}$ & 20 \\
\hline $\begin{array}{l}\text { Tasdelen et } \\
\text { al., [50] }\end{array}$ & & $\begin{array}{l}\text { Coro drill 880- } \\
\text { D1900L25-03; } \\
\text { Inserts GM } \\
\text { 1044- centrum }\end{array}$ & Drill dia. 19mm & $155 \mathrm{~m} / \mathrm{min}$ & $0.11 \mathrm{~mm} / \mathrm{rev}$ & 33 \\
\hline $\begin{array}{l}\text { Niketh and } \\
\text { Samuel }\end{array}$ & Ti-6Al-4V & & & $60 \mathrm{~m} / \mathrm{min}$ & $0.07 \mathrm{~mm} / \mathrm{rev}$ & \\
\hline
\end{tabular}

[51] 


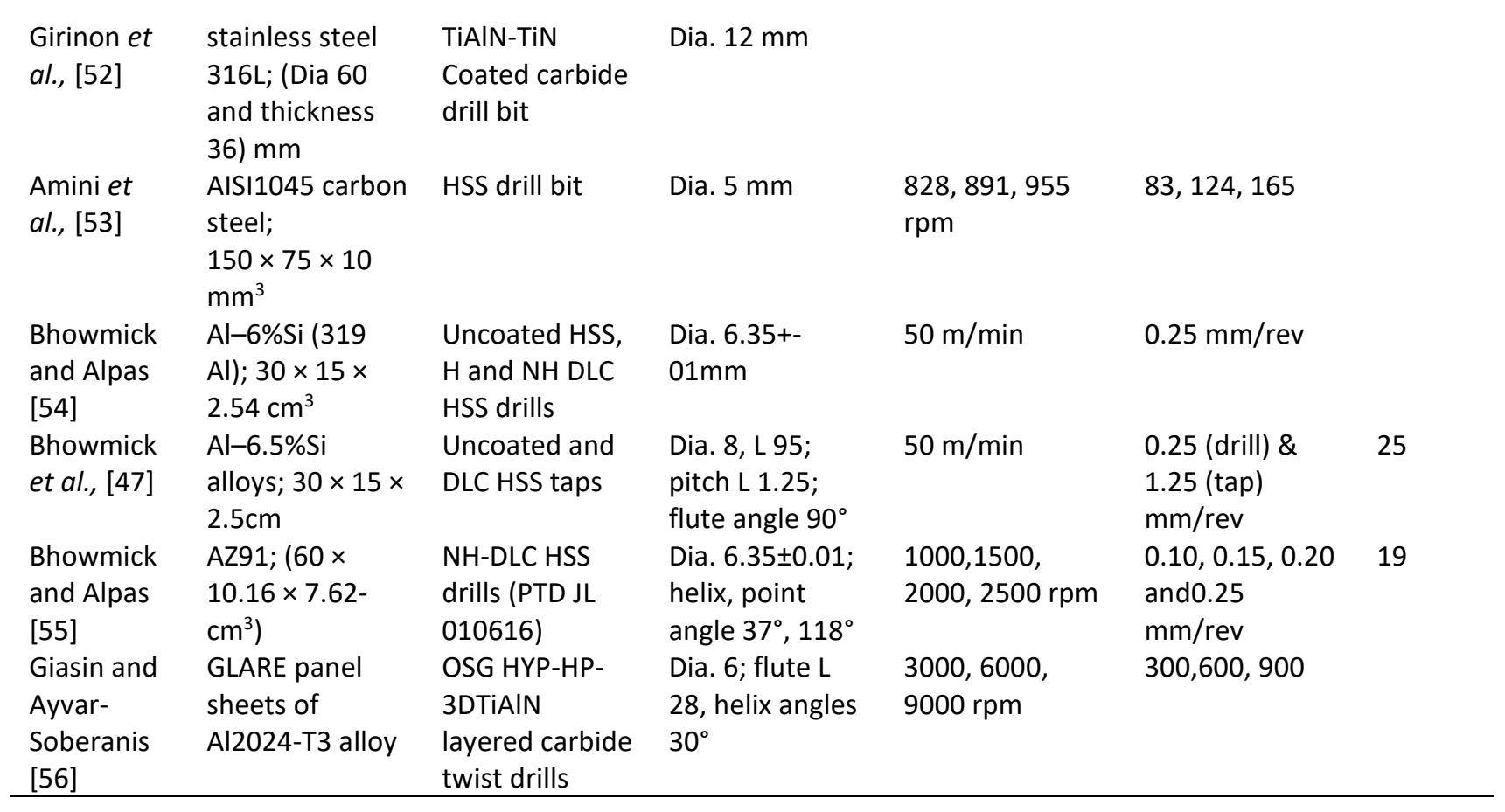

Table 6

Summary of lubrication mode, cutting fluids, other specifications of various coolant systems for drilling

\begin{tabular}{|c|c|c|c|c|c|c|}
\hline Authors & $\begin{array}{l}\text { Mode of } \\
\text { lubrication }\end{array}$ & $\begin{array}{l}\text { Cutting } \\
\text { fluid }\end{array}$ & $\begin{array}{l}\text { MQL \& flood } \\
\text { flow rate }\end{array}$ & $\begin{array}{l}\text { MQL air, fluid } \\
\text { pressure }\end{array}$ & $\begin{array}{l}\text { Nanoparticle, } \\
\text { WT\%, Spray } \\
\text { angle }\end{array}$ & $\begin{array}{l}\text { Other coolant } \\
\text { specification }\end{array}$ \\
\hline $\begin{array}{l}\text { Kuzu et al., } \\
\text { [58] }\end{array}$ & MQL & & $100 \mathrm{ml} / \mathrm{h}(\mathrm{MQL})$ & 6 Bar(air) & & \\
\hline $\begin{array}{l}\text { Chatha et al., } \\
\text { [59] }\end{array}$ & $\begin{array}{l}\text { Dry, Flood, } \\
\text { MQL, NF- MQL }\end{array}$ & $\begin{array}{l}\text { Soya Bea } \\
\text { Oil }\end{array}$ & $\begin{array}{l}200 \mathrm{ml} / \mathrm{h}(\text { oil), } \\
30,000 \mathrm{ml} / \mathrm{h} \\
\text { (flood) }\end{array}$ & 70 Psi(air) & $\begin{array}{l}\mathrm{Al}_{2} \mathrm{O}_{3} \text { of } 20 \\
\mathrm{~nm}, 1.5 \%\end{array}$ & \\
\hline $\begin{array}{l}\text { Biermann and } \\
\text { lovkov [44] }\end{array}$ & $\begin{array}{l}\text { Internal three- } \\
\text { channel MQL }\end{array}$ & & & 15 bar & & \\
\hline $\begin{array}{l}\text { Berzosa et al., } \\
\text { [45] }\end{array}$ & MQL & & $\begin{array}{l}0,50 \mathrm{ml} / \mathrm{h} \\
\text { (MQL) }\end{array}$ & & & \\
\hline $\begin{array}{l}\text { Kuzu et al., } \\
{[46]}\end{array}$ & $\begin{array}{l}\text { EXP-I-dry, EXP- } \\
\text { II- compressed } \\
\text { air, EXP- III- } \\
\text { MQL }\end{array}$ & & $5 \mathrm{ml} / \mathrm{h}(\mathrm{MQL})$ & $\begin{array}{l}690 \mathrm{kPa} \\
\text { (compressed } \\
\text { air) }\end{array}$ & & \\
\hline $\begin{array}{l}\text { Bhowmick et } \\
\text { al., [60] }\end{array}$ & $\begin{array}{l}\text { Dry, MQL, } \\
\text { Flooded }\end{array}$ & $\begin{array}{l}\text { i. H20- } \\
\text { MWQL ii. } \\
\text { FA_MQL } \\
\text { iii. Mineral } \\
\text { oil-Flooded }\end{array}$ & $\begin{array}{l}10 \mathrm{ml} / \mathrm{h}[\mathrm{i}, \mathrm{ii}] \\
30.0 \mathrm{l} / \mathrm{h} \text { (Flood) }\end{array}$ & & & \\
\hline $\begin{array}{l}\text { Heinemann et } \\
\text { al., [48] }\end{array}$ & $\begin{array}{l}\text { MQL_SE+add; } \\
\text { MQL_SE +add } \\
+20 \% \text { alcohol; } \\
\text { MQL_oil free } \\
\text { SL +40\% water }\end{array}$ & & $\begin{array}{l}18 \\
\mathrm{ml} / \mathrm{h}(\mathrm{MQL})\end{array}$ & & & \\
\hline $\begin{array}{l}\text { Le Coz et al., } \\
\text { [49] }\end{array}$ & Internal MQL & & & & & \\
\hline $\begin{array}{l}\text { Tasdelen et } \\
\text { al., [50] }\end{array}$ & $\begin{array}{l}\text { Air, emulsion, } \\
\text { MQL }\end{array}$ & & $\begin{array}{l}5,15,23 \mathrm{ml} / \mathrm{h} \\
\text { (MQL) }\end{array}$ & & & \\
\hline $\begin{array}{l}\text { Niketh and } \\
\text { Samuel [51] }\end{array}$ & Dry, Wet, MQL & & $200 \mathrm{ml} / \mathrm{h}$ (MQL) & 6 bar & & \\
\hline
\end{tabular}




\begin{tabular}{|c|c|c|c|c|c|}
\hline $\begin{array}{l}\text { Girinon et al., } \\
\text { [52] }\end{array}$ & $\begin{array}{l}\text { Dry, internal, } \\
\text { and external } \\
\text { coolant ( } 8.3 \% \\
\text { emulsion) }\end{array}$ & & & & \\
\hline $\begin{array}{l}\text { Amini et al., } \\
\text { [53] }\end{array}$ & $\begin{array}{l}\text { Ordinary, MQL, } \\
\text { UV, UV-MQL }\end{array}$ & $\begin{array}{l}\text { Accu-lube } \\
\text { FG-2000 }\end{array}$ & $100 \mathrm{ml} / \mathrm{h}$ (MQL) & 4 bar & $\begin{array}{l}\text { Injection } \\
\text { frequency } 10 \\
\text { cycle/min }\end{array}$ \\
\hline $\begin{array}{l}\text { Bhowmick and } \\
\text { Alpas [54] }\end{array}$ & MQL & $\begin{array}{l}\text { Distilled } \\
\text { Water }\end{array}$ & $30 \mathrm{ml} / \mathrm{h}$ (MQL) & & \\
\hline $\begin{array}{l}\text { Bhowmick et } \\
\text { al., [47] }\end{array}$ & $\begin{array}{l}\text { Dry, FA-MQL; } \\
\text { MO-MQL; } \\
\text { Flood }\end{array}$ & $\begin{array}{l}\text { Mineral- } \\
\text { based tap } \\
\text { Oil, Fatty } \\
\text { acid Based } \\
\text { MQL }\end{array}$ & $\begin{array}{l}80 \mathrm{ml} / \mathrm{h} \text { (FA- } \\
\mathrm{MQL}), 10,000 \\
\mathrm{ml} / \mathrm{hr} \text { (flood) }\end{array}$ & & \\
\hline $\begin{array}{l}\text { Bhowmick and } \\
\text { Alpas [55] }\end{array}$ & MQL & $\begin{array}{l}\text { Distilled } \\
\text { water } \\
\text { (MQL); } \\
\text { Mineral oil } \\
\text { (flood) }\end{array}$ & $\begin{array}{l}30 \mathrm{ml} / \mathrm{h}(\mathrm{MQL}) \\
30,000 \mathrm{ml} / \mathrm{h} \\
\text { (Flood) }\end{array}$ & $0.6 \mathrm{MPa}$ (air) & \\
\hline $\begin{array}{l}\text { Giasin and } \\
\text { Ayvar- } \\
\text { Soberanis [56] }\end{array}$ & $\begin{array}{l}\text { Cryogenic } \\
\text { Liquid Nitrogen } \\
\text { cooling, MQL }\end{array}$ & & $\begin{array}{l}20,40,60 \mathrm{ml} / \mathrm{h} \\
(\mathrm{MQL})\end{array}$ & 1, 2, 3 bar (air) & \\
\hline
\end{tabular}

Table 7

Summary of experimental results of different lubrication systems for drilling of various workpieces

\begin{tabular}{|c|c|c|c|}
\hline Authors & $\begin{array}{l}\text { Workpiece } \\
\text { Material }\end{array}$ & $\begin{array}{l}\text { Mode of } \\
\text { Lubrication }\end{array}$ & Findings \\
\hline Kuzu et al., [58] & CGI & MQL & $\begin{array}{l}\text { Heat energy increased by twice for increasing cutting speed } \\
\text { from } 25 \text { to } 50 \mathrm{~m} / \mathrm{min} \text {, whereas thrust and torque values are } \\
\text { equal. }\end{array}$ \\
\hline $\begin{array}{l}\text { Chatha et al., } \\
{[59]}\end{array}$ & $\begin{array}{l}\text { Aluminum } \\
6063\end{array}$ & $\begin{array}{l}\text { Dry, Flood, } \\
\text { Pure MQL, NF- } \\
\text { MQL }\end{array}$ & $\begin{array}{l}\text { NF- MQL technique shows an increased number of drilled } \\
\text { holes, less cutting and friction forces, torques and surface } \\
\text { roughness, and improved tool life, compared with the dry } \\
\text { and flooded conditions. }\end{array}$ \\
\hline $\begin{array}{l}\text { Biermann and } \\
\text { lovkov [44] }\end{array}$ & EN AC-46000 & $\begin{array}{l}\text { Internal MQL } \\
\text { supply }\end{array}$ & $\begin{array}{l}\text { The high feed process shows better productivity and less } \\
\text { heat in the workpiece during drilling. }\end{array}$ \\
\hline $\begin{array}{l}\text { Berzosa et al., } \\
{[45]}\end{array}$ & UNS M11917 & MQL & $\begin{array}{l}\text { Smallest and largest surface roughness values are } 0.13 \mu \mathrm{m} \\
\text { and } 0.87 \mu \mathrm{m} \text {, respectively. } \\
\text { At less cutting speed with higher feed rates exerts lower } \\
\text { surface roughness. }\end{array}$ \\
\hline Kuzu et al., [46] & $\begin{array}{l}\text { CGI- } \\
\text { Compacted } \\
\text { Graphite Iron }\end{array}$ & $\begin{array}{l}\text { EXP-I dry, EXP- } \\
\text { II dry with } \\
\text { compressed } \\
\text { air, EXP- III- } \\
\text { MQL }\end{array}$ & $\begin{array}{l}\text { Almost the same cutting force and torque required for all } \\
\text { three conditions. } \\
\text { MQL provides better lubrication but generates long chips } \\
\text { which are difficult to evacuate, leading to low tool life. }\end{array}$ \\
\hline $\begin{array}{l}\text { Bhowmick et } \\
\text { al., [60] }\end{array}$ & AM60 & $\begin{array}{l}\text { Dry, MQL, } \\
\text { Flooded }\end{array}$ & $\begin{array}{l}\text { The drilling performance was stable for both } \mathrm{H}_{2} \mathrm{O}-\mathrm{MQL} \text { and } \\
\mathrm{FA}-\mathrm{MQL} \text { conditions. } \\
\text { At MQL, the workpiece's maximum temperature is } \\
\text { comparable to flooded conditions and much less than dry. }\end{array}$ \\
\hline $\begin{array}{l}\text { Heinemann et } \\
\text { al., [48] }\end{array}$ & $\begin{array}{l}\text { Plain carbon } \\
\text { steel }(0.45 \% \\
\text { carbon); }\end{array}$ & $\begin{array}{l}\text { MQL_SE+add; } \\
\text { MQL_SE +add } \\
+20 \% \text { alcohol; } \\
\text { MQL_oil free } \\
\text { SL +40\% water }\end{array}$ & $\begin{array}{l}\text { Dry drilling accelerates tool wear significantly. } \\
\text { Excellent cooling capability with lower viscosity type } \\
\text { lubricant gives prolonged tool life. } \\
\text { Tool life degradation seen for discontinuous MQL supply. }\end{array}$ \\
\hline
\end{tabular}




\begin{tabular}{|c|c|c|c|}
\hline $\begin{array}{l}\text { Le Coz et al., } \\
\text { [49] }\end{array}$ & $\begin{array}{l}\text { Ti6Al4V } \\
\text { titanium } \\
\text { alloy }\end{array}$ & Internal MQL & $\begin{array}{l}\text { Maximum temperatures for drilling (MQL) and milling (Dry) } \\
\text { are } 160^{\circ} \text { and } 620^{\circ} \mathrm{C} \text { for a hole depth of } 20 \mathrm{~mm} \text { and cutting } \\
\text { length of } 500 \mathrm{~mm} \text {. }\end{array}$ \\
\hline $\begin{array}{l}\text { Tasdelen et al., } \\
\text { [50] }\end{array}$ & & $\begin{array}{l}\text { Air, Emulsion, } \\
\text { MQL }\end{array}$ & Air-assisted drilling and MQL show maximum cutting force. \\
\hline $\begin{array}{l}\text { Niketh and } \\
\text { Samuel [51] }\end{array}$ & Ti-6Al-4V & $\begin{array}{l}\text { Dry, Wet, } \\
\text { MQL }\end{array}$ & $\begin{array}{l}\text { Margin textured tool reduces thrust force } 10-12 \%, 15-20 \% \text {, } \\
15-19 \% \text { in dry, wet, and MQL conditions, respectively. }\end{array}$ \\
\hline $\begin{array}{l}\text { Girinon et al., } \\
{[52]}\end{array}$ & $\begin{array}{l}\text { austenitic } \\
\text { stainless } \\
\text { steel 316L }\end{array}$ & $\begin{array}{l}\text { Dry, internal } \\
\text { coolant } \\
(8.3 \%), \\
\text { external } \\
\text { coolant (8.3\%) }\end{array}$ & $\begin{array}{l}\text { Dry condition is severe in terms of chip morphology, forces, } \\
\text { and temperature. For the internal state, heat is carried } \\
\text { away by coolant, and residual stresses are compressive. }\end{array}$ \\
\hline $\begin{array}{l}\text { Amini et al., } \\
\text { [53] }\end{array}$ & $\begin{array}{l}\text { AISI1045 } \\
\text { carbon } \\
\text { steel }\end{array}$ & $\begin{array}{l}\text { Ordinary, UV, } \\
\text { MQL, and UV- } \\
\text { MQL }\end{array}$ & $\begin{array}{l}14 \% \text { and } 11 \% \text { reduction of thrust force and surface } \\
\text { roughness occurred by UV drilling. UV-MQL drilling } \\
\text { produces better surface quality for lower BUE generation. }\end{array}$ \\
\hline $\begin{array}{l}\text { Bhowmick and } \\
\text { Alpas [54] }\end{array}$ & $\begin{array}{l}\text { Al-6\%Si (319 } \\
\text { Al) }\end{array}$ & MQL & $\begin{array}{l}\mathrm{NH}-\mathrm{DLC} \text { coating is preferable for drilling Al-Si than H-DLC } \\
\text { coated drills because this coating showed minimum torque, } \\
\text { BUE, thrust force, and less aluminum adhesion on the flute. }\end{array}$ \\
\hline $\begin{array}{l}\text { Bhowmick et } \\
\text { al., [47] }\end{array}$ & $\begin{array}{l}\text { Al-6.5\%Si } \\
\text { (319 Al) } \\
\text { alloys }\end{array}$ & $\begin{array}{l}\text { Dry, FA-MQL; } \\
\text { MO-MQL; } \\
\text { Flood }\end{array}$ & $\begin{array}{l}\text { MQL drilling shows } 55^{\circ} \mathrm{C} \text { temperature reduction and lower } \\
\text { average torque, which is similar to flooded condition. }\end{array}$ \\
\hline $\begin{array}{l}\text { Bhowmick and } \\
\text { Alpas [55] }\end{array}$ & $\begin{array}{l}\text { AZ91; Mg- } \\
\text { Al-Zn }\end{array}$ & MQL & $\begin{array}{l}30 \mathrm{ml} / \mathrm{h} \text { flow rate of } \mathrm{H}_{2} \mathrm{O}-\mathrm{MQL} \text { drilling reduces friction, } \\
\text { torque, temperature, and enhancement of } \mathrm{NH}-\mathrm{DLC} \text { drills. }\end{array}$ \\
\hline $\begin{array}{l}\text { Giasin and } \\
\text { Ayvar- } \\
\text { Soberanis [56] }\end{array}$ & $\begin{array}{l}\text { Fiber metal } \\
\text { laminates } \\
\text { (FMLs) }\end{array}$ & $\begin{array}{l}\text { LN2 cooling, } \\
\text { MQL }\end{array}$ & $\begin{array}{l}\text { MQL and cryogenic cooling reduce waste generation. } \\
\text { Increased spindle speed and feed rate deteriorate borehole } \\
\text { surface. }\end{array}$ \\
\hline
\end{tabular}

\subsection{MQL in Milling}

In a milling machine, end milling is a slot cutting technique, making flat surfaces and even complex profiles by end mills. End Milling is associated with a better material removal rate, a simple setup with minimum cost, and most importantly, creating various products with different shapes for many applications through this machining. Optimization of end milling machining parameters is essential due to this operation's significant role in the recent manufacturing world. Khatri and Jahan [4] performed end milling on TI-6Al-4V alloy for comparatively higher cutting speed and various feed depth of cut while both coated and uncoated tools used. They suggested that abrasion is the most preeminent type of tool wear for all machining conditions, e.g., flood, MQL, dry. Abrasion wear is comparatively low in MQL than dry machining and least in flood machining, and it found to be dominant in flank and rake faces which faces contributing most to tool life and surface integrity. Chipping and adhesion are the second most prevalent wear that occurs most in dry and least in MQL condition. Some plastic failures of flutes and edges observed in flood and dry machining than MQL machining. Moreover, delamination was less significant in dry drilling than MQL and flood machining due to the efficacy of coated tools. Finally, they concluded that MQL is the sustainable machining condition over dry and flood machining, which is liable for the least tool wears. Again, wear analysis of uncoated and PVD coated TiAIN and AITiN tools was accomplished by Bandapalli et al., [61] while performing micro end milling of 12 grade Ti alloy (Ti-0.3Mo-0.8Ni) under dry condition. In this study, speed and feed found to be the most prevalent variables affecting the tool wear. Moreover, wear of the tool can be attenuated for AITiN coated and uncoated WC tool while increasing cutting speed (at 70,000 and 1,10,000 rpm) and without changing feed and depth of cut. In addition, it is recommended from the investigation that the uncoated WC tool is superior to AITiN and TiAIN tools for high-speed milling of 12-grade Titanium alloy. During conventional milling of Al6061-T6 using WC tool 
(AE302100) at $5000 \mathrm{rpm} / \mathrm{min}$ speed, $100 \mathrm{~mm} / \mathrm{min}$ feed, $5 \mathrm{~mm}$ depth of cut for $0.0,0.2,0.5$, and 1.0 wt\% nanolubricant, $3.87 \%$ improvement of surface roughness is reported with $0.5 \mathrm{wt} \% \mathrm{MoS}_{2}$ nanolubricants MQL system compared with pure oil [62]. Similarly, in the case of end milling of stainless steel, the performance of MQL excelled over dry and flood machining conditions in terms of tool life and surface roughness [63]. In this experiment, vegetable oil used as the base fluid and TiAIN multilayers coated carbide tools. Uysal et al., [64] also performed the milling process on AISI420 under MQL and even with one wt\% $\mathrm{MoS}_{2}$ nanoparticle into the MQL system. This investigation was conducted at $995 \mathrm{rpm}$ speed, 5 bar pressure, $20 \mathrm{ml} / \mathrm{h}$, and $40 \mathrm{ml} / \mathrm{h}$ flow rates of MQL. However, the $40 \mathrm{ml} / \mathrm{h}$ flow rate of MQL shows the best results both for tool wear and surface roughness. They revealed that $9.8 \%$ and $15.5 \%$ tool wear reduction is possible at $20 \mathrm{ml} / \mathrm{h}$ and $40 \mathrm{ml} / \mathrm{h}$ flow rates, respectively, for an ordinary MQL system.

On the contrary, for the NF- MQL system, $16.8 \%$ and $19.9 \%$ tool wear reduction reported at 20 $\mathrm{ml} / \mathrm{h}$ and $40 \mathrm{ml} / \mathrm{h}$ flow rates compared to dry milling. Moreover, the minimum value $(0.8644 \mu \mathrm{m})$ of surface roughness derived from the NF- MQL system at a $40 \mathrm{ml} / \mathrm{h}$ flow rate. Finally, they concluded that increment of fluid flow rate with nanoparticles' inclusion gives lower tool wear and higher surface integrity because the nanoparticles dispersion into the traditional fluid improves thermophysical properties showing good stability [65]. Hence, the NF-MQL system functions as a better cooling and lubrication system. Wang et al., [66] suggested the optimal cutting parameters of up and down milling of Inconel 182. The investigation was performed under MQL and dry conditions while using the $\mathrm{S} / \mathrm{N}$ ratio. It is evident from the study that surface roughness is not prone to lubrication mode at $160 \mathrm{~mm} / \mathrm{min}$ speed, $0.2 \mathrm{~mm} /$ tooth feed rate, $1 \mathrm{~mm}$ depth of cut, and for down milling, surface roughness remarkably increases when MQL is applied. In up milling, tool wear is significant, and MQL works significantly. In reverse, MQL shows ineffectiveness for down milling operation due to unstable milling processes or significant self-excited vibration. In terms of energy consumption, up milling needs less energy compared with down milling. So, they concluded that tool waste and manufacturing costs significantly reduced by using up milling with MQL during machining Inconel 182 [66]. In the investigation of spray cooling with MQL for milling machining of Ti-6Al-4V alloy, spray angle of $90^{\circ}$ is not appropriate from the lubrication prospect using WC tool as MQL droplets rarely enter into the cutting zone despite showing a lower temperature for $0^{\circ}$ and $90^{\circ}$ of spray angle in comparison of $45^{\circ}$ spray angle [67]. Again, for end milling of AISI 4140 steel using carbide end mill cutter under MQL system, it is found that cutting energy is most significantly affected by speed, feed, and last but not least MQL flow rate, whereas surface roughness notably impacted by the flow rate of MQL and also cutting speed [68]. Comparison among dry, wet, $\mathrm{CO}_{2}$ stand-alone, MQL system was made by Pereira et al., [69], and the proposed hybrid $\mathrm{CO}_{2}+\mathrm{MQL}$ lubrication system while investigated the cooling process of Inconel 718 during milling machining. From their experiment, surface integrity not demonstrated clearly, and it found that better lubrication cannot be derived from a higher speed. They concluded that the tool life shows the best results being over $90 \%$ more eco-friendly at a $100 \mathrm{ml} / \mathrm{h}$ flow rate of oil than wet machining [69]. 


\section{Table 8}

Summary of various machining parameters for milling operation

\begin{tabular}{|c|c|c|c|c|c|c|c|}
\hline References & Machining & $\begin{array}{l}\text { Workpiece } \\
\text { material and } \\
\text { geometry }\end{array}$ & $\begin{array}{l}\text { Cutting Tool } \\
\text { Material }\end{array}$ & $\begin{array}{l}\text { Tool } \\
\text { Geometry }\end{array}$ & $\begin{array}{l}\text { Cutting } \\
\text { Speed }\end{array}$ & Feed & $\begin{array}{l}\text { Depth } \\
\text { of cut }\end{array}$ \\
\hline $\begin{array}{l}\text { Khatri and } \\
\text { Jahan [4] }\end{array}$ & $\begin{array}{l}\text { End } \\
\text { milling }\end{array}$ & Ti-6Al-4V & $\begin{array}{l}\text { Uncoated and } \\
\text { TiAIN tools }\end{array}$ & & $50 \mathrm{~m} / \mathrm{min}$ & $\begin{array}{l}0.1,0.3, \\
0.5 \mathrm{~mm} / \mathrm{rev}\end{array}$ & $\begin{array}{l}0.2,0.3, \\
0.4,0.5\end{array}$ \\
\hline $\begin{array}{l}\text { Rahmati et } \\
\text { al., [62] }\end{array}$ & $\begin{array}{l}\text { End } \\
\text { milling }\end{array}$ & $\begin{array}{l}\text { Al6061-T6 } \\
(40 \times 40 \times 100 \\
\left.\mathrm{mm}^{3}\right)\end{array}$ & $\begin{array}{l}\text { WC tool } \\
\text { (AE302100) }\end{array}$ & $\begin{array}{l}2 \text { flutes } \\
\text { with } 10 \mathrm{~mm} \\
\text { dia. }\end{array}$ & $5000 / \min$ & $100 \mathrm{~mm} / \mathrm{min}$ & 5 \\
\hline $\begin{array}{l}\text { Bandapalli } \\
\text { et al., [61] }\end{array}$ & $\begin{array}{l}\text { Micro end } \\
\text { milling }\end{array}$ & $\begin{array}{l}\text { Ti Alloy-Ti- } \\
0.30 \mathrm{Mo}- \\
0.8 \mathrm{Ni}(60 \times 40 \\
\times 4 \mathrm{~mm})\end{array}$ & $\begin{array}{l}\text { Uncoated, } \\
\text { PVD coated } \\
\text { AITiN, TiAIN } \\
\text { WC }\end{array}$ & $\begin{array}{l}\text { Dia. } 500 \\
\text { Microns; } \\
\text { rake angle } \\
+5^{\circ}\end{array}$ & $\begin{array}{l}47,110 \text { and } \\
173 \mathrm{~m} / \mathrm{min}\end{array}$ & $\begin{array}{l}2,5 \& 8 \\
\mu \mathrm{m} / \text { tooth }\end{array}$ & $\begin{array}{l}0.02 \\
0.06 \\
0.1\end{array}$ \\
\hline $\begin{array}{l}\text { Uysal et al., } \\
{[64]}\end{array}$ & Milling & $\begin{array}{l}\text { AISI420 } \\
\text { martensitic } \\
\text { stainless } \\
\text { Steel }\end{array}$ & $\begin{array}{l}\text { SPHN120404 } \\
\text { uncoated WC }\end{array}$ & $\begin{array}{l}\text { Dia. } 32 \mathrm{~mm} \\
\text { end } \\
\text { mill }\end{array}$ & 995 rpm & $180 \mathrm{~mm} / \mathrm{min}$ & 0.5 \\
\hline $\begin{array}{l}\text { Wang et } \\
\text { al., [66] }\end{array}$ & $\begin{array}{l}\text { Face } \\
\text { Milling } \\
\text { (Up \& } \\
\text { Down) }\end{array}$ & $\begin{array}{l}\text { Inconel } 182 \\
(80 \times 40 \times 40 \\
\mathrm{mm})\end{array}$ & $\begin{array}{l}\text { Sandvik } \\
\text { milling cutter } \\
\text { R390-050Q22- } \\
\text { 17M }\end{array}$ & $\begin{array}{l}\text { Dia. } 50 \text { mm; } \\
\text { insert- } \\
\text { Sandvik } \\
\text { R390-17 } 04 \\
\text { 08M }\end{array}$ & $\begin{array}{l}V=80,120, \\
160 \mathrm{~m} / \mathrm{min}\end{array}$ & $\begin{array}{l}0.1,0.2, \\
0.3 \mathrm{~mm} / \text { tooth }\end{array}$ & $\begin{array}{l}\text { Width } \\
40 \\
\text { depth } \\
0.5,1 \\
1.5\end{array}$ \\
\hline $\begin{array}{l}\text { Kim et al., } \\
{[67]}\end{array}$ & Milling & $\begin{array}{l}\text { Ti-6Al }-4 \mathrm{~V} \\
(40 \times 20 \mathrm{~mm})\end{array}$ & WC & $\begin{array}{l}\text { Radius } 8 \\
\mathrm{~mm}\end{array}$ & $\begin{array}{l}1000 \\
\mathrm{rev} / \mathrm{min}\end{array}$ & $0.48 \mathrm{~mm} / \mathrm{rev}$ & $\begin{array}{l}\text { Radial } \\
\text { depth } \\
\text { of cut } 4\end{array}$ \\
\hline $\begin{array}{l}\text { Pereira et } \\
\text { al., [69] }\end{array}$ & Milling & $\begin{array}{l}\text { Inconel } \\
718(45 \mathrm{HRC})\end{array}$ & & & $120 \mathrm{~m} / \mathrm{min}$ & & \\
\hline Kumar [74] & $\begin{array}{l}\text { Micro end } \\
\text { milling }\end{array}$ & $\begin{array}{l}\text { Copper alloy } \\
\text { C360 }\end{array}$ & $\begin{array}{l}\text { WC flat end } \\
\text { mill }\end{array}$ & $\begin{array}{l}\text { size } 700 \mu \mathrm{m} \\
\& 800 \mu \mathrm{m}\end{array}$ & & & $\begin{array}{l}\text { Depth \& } \\
\text { length } \\
\text { of cut } \\
70 \mu \mathrm{m} \\
10\end{array}$ \\
\hline $\begin{array}{l}\text { Tunc et al., } \\
{[70]}\end{array}$ & $\begin{array}{l}\text { Robotic } \\
\text { Milling }\end{array}$ & $\begin{array}{l}\text { AISI316L; (50 } \\
\mathrm{mm} \times 110 \\
\mathrm{~mm})\end{array}$ & $\begin{array}{l}\text { Three flutes } \\
\text { inserted } \\
\text { cutter }\end{array}$ & Dia. 25 mm & $\begin{array}{l}1800 \mathrm{rpm} \\
(140 \mathrm{~m} / \mathrm{min})\end{array}$ & $0.1 \mathrm{~mm} / \mathrm{rev}$ & 1.5 \\
\hline $\begin{array}{l}\text { Kedare et } \\
\text { al., [71] }\end{array}$ & $\begin{array}{l}\text { End } \\
\text { Milling }\end{array}$ & $\begin{array}{l}\text { Bright Mild } \\
\text { Steel }(100 \times \\
110 \times 25)\end{array}$ & $\begin{array}{l}\text { Four flutes, } \\
\text { HSS end mill } \\
\text { (uncoated) }\end{array}$ & $\begin{array}{l}\text { Dia. } 5 \mathrm{~mm} \text {; } \\
\text { axial rake } \\
\text { angle } 5^{\circ}\end{array}$ & $\begin{array}{l}160,225,300 \\
\mathrm{rpm}\end{array}$ & constant & $\begin{array}{l}0.1,0.2, \\
\text { and } 0.3\end{array}$ \\
\hline $\begin{array}{l}\text { Iskandar et } \\
\text { al., [72] }\end{array}$ & Milling & $\begin{array}{l}\text { Carbon fibre } \\
\text { reinforced } \\
\text { plastics } \\
\text { (CFRP) }\end{array}$ & $\begin{array}{l}\text { Uncoated WC } \\
\text { end mills } \\
\text { (SGS- } \\
\text { 30131). }\end{array}$ & $\begin{array}{l}\text { Helical 4- } \\
\text { flutes } \\
1 / 400\end{array}$ & $15,000 \mathrm{rpm}$ & $1500 \mathrm{~mm} / \mathrm{min}$ & $\begin{array}{l}\text { cutting } \\
\text { length } \\
90\end{array}$ \\
\hline $\begin{array}{l}\text { Liao et al., } \\
\text { [73] }\end{array}$ & $\begin{array}{l}\text { End } \\
\text { Milling }\end{array}$ & $\begin{array}{l}\text { NAK } 80 \text { mold } \\
\text { steel ( } 41 \\
\text { HRc) }\end{array}$ & $\begin{array}{l}\text { TiAIN and TiN } \\
\text { layered } \\
\text { carbide tool }\end{array}$ & & $\begin{array}{l}300 \text { to } 500 \\
\mathrm{~m} / \mathrm{min}\end{array}$ & $\begin{array}{l}0.1,0.2 \\
\mathrm{~mm} / \mathrm{rev}\end{array}$ & $\begin{array}{l}\text { axial } \\
0.3 ; 5\end{array}$ \\
\hline
\end{tabular}

Tunc et al., [70] reported surface roughness, and residual stress of austenitic stainless steel during MQL assisted robotic milling. They found that MQL settings, having a hardly prominent effect on surface roughness and tensile residual stress, increases with decreasing oil flow rate. So, they finally suggested a well-controlled flow rate and duty cycle for reducing residual stress in the milling process. However, $27 \%$ improvement of surface roughness is possible during end milling of mild steel under $900 \mathrm{ml} / \mathrm{h}$ flow rate of MQL while uncoated end mill cutter of HSS used, and it is also evident that MQL works efficiently at less speed and depth of cut [71]. Iskandar et al., [72] conducted experiments to establish optimum MQL conditions by considering various parameters such as flow rate of oil and air, 
spray angle, nozzle distance, and flow characteristics of the milling process of carbon fiber reinforced plastics (CFRP). The study uncovers that if the nozzle placed near the cutting zone, optimum MQL spray achieved from low oil and high airflow rate, verified from Phase Doppler Anemometry and Particle image velocimetry. It found that for MQL condition, flank wear is reduced by $30 \%$ compared to pressurized air and $22 \%$ compared to dry and wet conditions. Cutting temperature reduced by using a cutting fluid of low viscosity at lower cutting speed; on the contrary, cutting fluid of greater viscosity contributes to improving cooling capability at higher cutting speeds, and the combination of superior heat resistant, coated carbide tool with MQL gives better tool life compared with other methods [73]. Machining with MQL concluded as a replacement and economical alternative to dry and flood cooling as it dramatically reduces lubricant consumption, especially when ecology and operators' physiology is an important issue [71]. Finally, Table 8 and Table 9 represent the summary of details information of machining parameters, lubrication mode, cutting fluid for milling operation, and Table 10 summarizes the investigations' findings.

\section{Table 9}

Summary of lubrication mode, cutting fluids, other specifications of various coolant systems for milling

\begin{tabular}{|c|c|c|c|c|c|c|}
\hline Authors & $\begin{array}{l}\text { Mode of } \\
\text { Lubrication }\end{array}$ & $\begin{array}{l}\text { Cutting } \\
\text { fluid }\end{array}$ & $\begin{array}{l}\text { MQL \& Flood } \\
\text { Flow Rate }\end{array}$ & $\begin{array}{l}\text { MQL Air and } \\
\text { Fluid } \\
\text { Pressure }\end{array}$ & $\begin{array}{l}\text { Nanoparticles, } \\
\text { wt\% \& Spray } \\
\text { angle }\end{array}$ & $\begin{array}{l}\text { Other coolant } \\
\text { Specification }\end{array}$ \\
\hline $\begin{array}{l}\text { Rahmati } \\
\text { et al., } \\
{[62]}\end{array}$ & MQL & $\begin{array}{l}\text { ECOCUT } \\
\text { HSG 905S } \\
\text { FUCHS }\end{array}$ & $30 \mathrm{ml} / \mathrm{min}$ & $\begin{array}{l}20 \text { Mpa. } \\
\text { (Oil); } 4 \text { bars } \\
\text { (Air) }\end{array}$ & $\begin{array}{l}0.0,0.2,0.5 \& \\
1.0 w t \%, 60^{\circ}\end{array}$ & $\begin{array}{l}\text { nozzle's orifice dia. } \\
1 \mathrm{~mm}\end{array}$ \\
\hline $\begin{array}{l}\text { Uysal et } \\
\text { al., [64] }\end{array}$ & MQL & $\begin{array}{l}\text { Eraoil } \\
\text { KT/2000 } \\
\text { vegetable } \\
\text { oil }\end{array}$ & $\begin{array}{l}\text { Oil-20 ml/h; } \\
\text { Nanolfuid-40 } \\
\mathrm{ml} / \mathrm{h}\end{array}$ & 5 bar & $1 \mathrm{wt} \% \mathrm{MoS}_{2}$ & $\begin{array}{l}\text { Nozzle dia., distance } \\
\text { and angle } 1 \mathrm{~mm}, 50 \\
\mathrm{~mm} \text { and } 10^{\circ}\end{array}$ \\
\hline $\begin{array}{l}\text { Wang et } \\
\text { al., [66] }\end{array}$ & Dry, MQL & & $125 \mathrm{~L} / \mathrm{min}$ (air) & $0.7 \mathrm{MPa}$ (air) & & $\begin{array}{l}\text { Elevation angle } 30^{\circ} \text {, } \\
\text { spray angle } 45^{\circ}\end{array}$ \\
\hline $\begin{array}{l}\text { Kim et } \\
\text { al., [67] }\end{array}$ & MQL & $\begin{array}{l}\text { Vegetable } \\
\text { oil }\end{array}$ & $\begin{array}{l}\text { Oil- } 3.32 \\
\mathrm{ml} / \mathrm{min} \text {; air- } \\
1362 \mathrm{ml} / \mathrm{min}\end{array}$ & & $0^{\circ}, 90^{\circ}, 45^{\circ}$ & $\begin{array}{l}\text { Nozzle dia \& } \\
\text { distance } 1.7 \mathrm{~mm} 7 \\
23 \mathrm{~mm} \text {; MQL } \\
\text { droplet avg. dia. } \\
11.2 \mu \mathrm{m}\end{array}$ \\
\hline $\begin{array}{l}\text { Pereira et } \\
\text { al., [69] }\end{array}$ & $\begin{array}{l}\text { Dry, wet, } \mathrm{CO}_{2} \text {, } \\
\mathrm{MQL}, \\
\mathrm{CO}_{2}+\mathrm{MQL}\end{array}$ & $\begin{array}{l}\text { Vegetable } \\
\text { oil }\end{array}$ & $100 \mathrm{ml} / \mathrm{h}$ & $\begin{array}{l}\text { Wet- } 6 \text { bar; } \\
\text { Cryogenic- } \\
14 \text { bar }\end{array}$ & & $\begin{array}{l}\mathrm{MQL}-100 \mathrm{ml} / \mathrm{h}+ \\
\mathrm{CO} 2-14 \text { bar } \&-80^{\circ} \mathrm{C}\end{array}$ \\
\hline $\begin{array}{l}\text { Tunc et } \\
\text { al., [70] }\end{array}$ & MQL & & $\begin{array}{l}75,140,280 \\
600 \mathrm{ml} / \mathrm{h} ; \\
0.04,0.08 \mathrm{ml} / \\
\text { stroke; }\end{array}$ & Air- 6, 7 bar & & $\begin{array}{l}\text { Duty Cycle } 75,140 \text {, } \\
280,600 \\
\text { strokes/min; nozzle } \\
\text { to tooltip distance } \\
30 \mathrm{~mm}\end{array}$ \\
\hline $\begin{array}{l}\text { Kedare et } \\
\text { al., [71] }\end{array}$ & MQL + Flood & & $\begin{array}{l}900 \mathrm{ml} / \mathrm{hr} \\
\text { (MQL); } 2 \\
\text { litre/h (Flood) }\end{array}$ & 5 bar & & $\begin{array}{l}\text { Nozzle dia } 3 \mathrm{~mm} ; \\
\text { spot distance } 20 \mathrm{~mm}\end{array}$ \\
\hline $\begin{array}{l}\text { Iskandar } \\
\text { et al., } \\
{[72]}\end{array}$ & $\begin{array}{l}\text { Dry, MQL, } \\
\text { Pressurized } \\
\text { air, flood }\end{array}$ & & $\begin{array}{l}\text { Air- 20, 25, } 28 \\
\text { I/min; oil- } 10 \\
17.5,24 \mathrm{l} / \mathrm{min}\end{array}$ & & & $\begin{array}{l}\text { Nozzle distance to } \\
\text { the cutting zone } 40 \text {, } \\
60,80 \mathrm{~mm}\end{array}$ \\
\hline $\begin{array}{l}\text { Liao et } \\
\text { al., [73] }\end{array}$ & $\begin{array}{l}\text { Dry, MQL, } \\
\text { Flood }\end{array}$ & ES3, ES1 & $\begin{array}{l}\text { Oil Mist-10 } \\
\mathrm{ml} /\end{array}$ & $0.45 \mathrm{MPa}$ & & \\
\hline
\end{tabular}




\section{Recommendation for Future Work}

Numerous researchers have studied the MQL technique in different kinds of machining, mostly with conventional fluids and some with nanofluids. There are some discrepancies in the research findings. For example, a few researchers found no significant difference in tool life during drilling of AISI4140 steel (24-26 RC) using oxide coated HSS drills and found minor differences in tool life using grade SM-30 uncoated carbide tool between flood and MQL cooling [75]. Some reported dry drilling as more efficient in terms of sustainability, cost, and energy savings than dry with compressed air and MQL conditions as they found chip evacuation comparatively difficult in the MQL technique [56]. Some researchers revealed MQL as a more prominent cooling method in grinding hardened steel rather than soft steel for grinding forces and surface integrity $[76,77]$. In contrast, others found that MQL is appropriate for softer materials but not harder $[78,79]$. Further research can be done to resolve contradictory findings. Higher cutting speeds and higher viscous cutting fluids play a significant role in improving the cooling capability for cutting, but its correlation with MQL has not yet been explored [73]. Some researchers found the lowest axial force from the emulsion, the maximum cutting force from MQL and air-assisted drilling, and the highest surface roughness from air-assisted drilling [50]. Though most of the researchers found that surface roughness is noticeably affected by the MQL technique. Still, a few findings revealed that MQL settings show a hardly significant effect on surface roughness [70].

\section{Table 10}

Summary of experimental results of different lubrication systems for milling of various workpieces

\begin{tabular}{|c|c|c|c|}
\hline Authors & $\begin{array}{l}\text { Workpiece } \\
\text { Material }\end{array}$ & $\begin{array}{l}\text { Mode of } \\
\text { Lubrication }\end{array}$ & Findings \\
\hline $\begin{array}{l}\text { Khatri and } \\
\text { Jahan [4] }\end{array}$ & Ti-6Al-4V & $\begin{array}{l}\text { Dry, MQL, } \\
\text { Flood }\end{array}$ & $\begin{array}{l}\text { MQL is responsible for least tool wear leading to sustainable } \\
\text { and effective machining. }\end{array}$ \\
\hline $\begin{array}{l}\text { Rahmati et al., } \\
{[62]}\end{array}$ & $\begin{array}{l}\text { Al6061-T6 (Al- } \\
\text { Mg-Si) }\end{array}$ & $\mathrm{MQL}$ & Surface roughness improved by $3.87 \%$. \\
\hline $\begin{array}{l}\text { Bandapalli et } \\
\text { al., [61] }\end{array}$ & $\begin{array}{l}\text { Ti Alloy (Ti- } \\
0.30 \mathrm{Mo}-0.8 \mathrm{Ni})\end{array}$ & MQL & $\begin{array}{l}\text { Uncoated carbide tool shows a smaller amount of wear of } \\
\text { the tool than PVD coated TiAIN \& AITiN WC tools. AITiN tools } \\
\text { perform superior to TiAIN tools while machining. }\end{array}$ \\
\hline Uysal et al., [64] & AISI420 & MQL & $\begin{array}{l}\text { Under the MQL system, tool wear reduced by } 9.8 \% \text { and } \\
15.5 \% \text { at } 20 \mathrm{ml} / \mathrm{h} \text { and } 40 \mathrm{ml} / \mathrm{h} \text { flow rates, respectively. } \\
\text { Similarly, } 16.8 \%, 19.9 \% \text { tool wear reduction is noticed for the } \\
\text { NF- MQL flow }(20 \mathrm{ml} / \mathrm{h} \& 40 \mathrm{ml} / \mathrm{h}) \text { compared to dry milling. }\end{array}$ \\
\hline $\begin{array}{l}\text { Wang et al., } \\
{[66]}\end{array}$ & $\begin{array}{l}\text { Inconel } 182 \\
\text { overlays }\end{array}$ & Dry, MQL & $\begin{array}{l}\text { Under the MQL system, surface roughness increases } \\
\text { abnormally in the case of down milling. }\end{array}$ \\
\hline Kim et al., [67] & $\mathrm{Ti}-6 \mathrm{Al}-4 \mathrm{~V}$ & MQL & $\begin{array}{l}\text { The spray angle of } 90^{\circ} \text { unsuitable for the lubing purpose as } \\
\text { the MQL droplet hardly reaches the cutting zone. }\end{array}$ \\
\hline $\begin{array}{l}\text { Pereira et al., } \\
{[69]}\end{array}$ & Inconel 718 & $\begin{array}{l}\text { Dry, wet, } \\
\mathrm{CO}_{2}, \mathrm{MQL} \\
\mathrm{CO}_{2}+\mathrm{MQL}\end{array}$ & $\begin{array}{l}\text { At } 100 \mathrm{ml} / \mathrm{h} \text { oil flow rate of } \mathrm{MQL} \text {, the tool life shows the best } \\
\text { results being more sustainable than wet machining. }\end{array}$ \\
\hline Tunc et al., [70] & AISI316L & MQL, Flood & $\begin{array}{l}\text { MQL settings show a hardly significant effect on surface } \\
\text { roughness. }\end{array}$ \\
\hline $\begin{array}{l}\text { Kedare et al., } \\
{[71]}\end{array}$ & $\begin{array}{l}\text { Bright Mild } \\
\text { Steel } 15 \text { HRc }\end{array}$ & $\begin{array}{l}\text { Dry, MQL, } \\
\text { Pressurized } \\
\text { air, flood }\end{array}$ & $\begin{array}{l}27 \% \text { improvement in surface roughness achieved by MQL } \\
(900 \mathrm{ml} / \mathrm{h}) \text {. }\end{array}$ \\
\hline $\begin{array}{l}\text { Iskandar et al., } \\
{[72]}\end{array}$ & $\begin{array}{l}\text { Carbon fiber } \\
\text { reinforced } \\
\text { plastics (CFRP) }\end{array}$ & $\begin{array}{l}\text { Dry, MQL, } \\
\text { Flood }\end{array}$ & $\begin{array}{l}\text { MQL shows } 30 \% \text { less wear at the flank face than pressurized } \\
\text { air condition and } 22 \% \text { less wear than flood and dry } \\
\text { conditions. }\end{array}$ \\
\hline Liao et al., [73] & $\begin{array}{l}\text { NAK80 mold } \\
\text { steel ( } 41 \mathrm{HRc})\end{array}$ & $\begin{array}{l}\text { Dry, Flood, } \\
\text { MQL }\end{array}$ & $\begin{array}{l}\text { Combining superior heat-resistant, coated carbide tool with } \\
\text { MQL gives better tool life than other methods. }\end{array}$ \\
\hline
\end{tabular}


Some researchers added some other new techniques and different types of tools with the MQL system, such as. UV- MQL, $\mathrm{CO}_{2}+\mathrm{MQL}$, Cryogenic cooling. For example, under UV- MQL conditions, better surface quality is generated due to lower BUE, generation of broken chips, secure chip evacuation method, and lower friction and force [53]. Using cryogenic cooling severity of borehole surface damage is found less compared to MQL and dry drilling, whereas waste generation is found less in the MQL and cryogenic coolant system [56]. However, some MQL condition parameters, such as spray angle and distance, air pressure, flow rates, and the effects, including optimizing these parameters, have not been appropriately explored until now. Also, the impact of nanofluid and especially the hybrid nanofluids with MQL has not been unfolded yet broadly. So further attention can be paid to the implication of NF- MQL system during machining of various materials, including alloys in the practical field.

\section{Conclusion}

This paper systematically represents a comparative discussion of the MQL technique its application in various machining operations. Several studies concluded that MQL is an efficient substitute for flooded machining conditions, safe for operators' health and the environment. Moreover, the production cost decreased by using the MQL technique as it reduces the coolant cost. From this review article, the following remarks can be drawn

i. The application of the MQL system can reduce the temperature of the tool-chip interface significantly.

ii. UV and UV-MQL conditions produce lower BUE on the drill bit by reducing friction and cutting forces through broken chip formation.

iii. The NF- MQL technique can prolong tool life and improve surface integrity by reducing friction, cutting forces, and torques.

iv. Compared to dry and LB 2000 fluid by MQL technique, $12 \%$, and $46 \%$ tool life enhancement are possible, including $\mathrm{MoS}_{2}$ in the base oil and cutting zone.

v. Under MQL condition, the use of lubricant with low viscosity and high cooling capability can upgrade tool life.

vi. Due to the use of MQL, a noticeable reduction of cutting temperature and forces is possible for nozzle distances of 6-9 $\mathrm{mm}$ at 0.4MPa while turning medium carbon steel (AISI1045).

vii. $\mathrm{H}_{2} \mathrm{O}$ - The MQL drilling technique can also increase the NH-DLC drill's life by reducing the contact zone, cutting force, torque, and temperature.

viii. Under $\mathrm{CO}_{2}+\mathrm{MQL}$ condition, the tool life exerts excellent results over $90 \%$ more eco-friendly than wet machining.

So, it concluded that adapting MQL condition over general condition can bring potential improvement in machining, reduction in cost, and, most importantly, environmental-friendly working conditions.

\section{Acknowledgements}

The authors would like to thank University Malaysia Pahang for providing the laboratory facilities and the financial support under the University LEAP-3 FLAGSHIP Research Grants (Project number RDU172203), University Research Grants No. RDU190367 and Post-graduate Research Scheme PGRS1903167. 


\section{References}

[1] Dimla, Eric. "Development of an Innovative Tool Wear Monitoring System for Zero-Defect Manufacturing." International Journal of Mechanical Engineering and Robotics Research 7, no. 3 (2018): 305-312. https://doi.org/10.18178/ijmerr.7.3.305-312

[2] Yousefi, Sasan, and Mehdi Zohoor. "Effect of cutting parameters on the dimensional accuracy and surface finish in the hard turning of MDN250 steel with cubic boron nitride tool, for developing a knowledged base expert system." International Journal of Mechanical and Materials Engineering 14, no. 1 (2019): 1-13. https://doi.org/10.1186/s40712-018-0097-7

[3] Ju, C., L. P. Keranen, K. R. Haapala, D. J. Michalek, and J. W. Sutherland. "Issues associated with MQL implementation: effect on peripheral milling process performance and impact on machining economics." In ASME International Mechanical Engineering Congress and Exposition, vol. 42231, pp. 3-12. 2005. https://doi.org/10.1115/IMECE2005-79259

[4] Khatri, Ashutosh, and Muhammd P. Jahan. "Investigating tool wear mechanisms in machining of Ti-6Al-4V in flood coolant, dry and MQ conditions." Procedia Manufacturing $26 \quad$ (2018): $434-445$. https://doi.org/10.1016/i.promfg.2018.07.051

[5] Lawal, Sunday Albert, Imtiaz Ahmed Choudhury, and Yusoff Nukman. "A critical assessment of lubrication techniques in machining processes: a case for minimum quantity lubrication using vegetable oil-based lubricant." Journal of Cleaner Production 41 (2013): 210-221. https://doi.org/10.1016/i.jclepro.2012.10.016

[6] Wakabayashi, Toshiaki, Junji Kuhara, Toshifumi Atsuta, Akira Tsukuda, Norio Sembongi, Junichi Shibata, and Satoshi Suda. "Near-dry machining of titanium alloy with MQL and hybrid mist supply." In Key Engineering Materials, vol. 656, pp. 341-346. Trans Tech Publications Ltd, 2015. https://doi.org/10.4028/www.scientific.net/KEM.656-657.341

[7] Madhukar, Samatham, Aitha Shravan, Pakka Vidyanand, and G. Sreeram Reddy. "A critical review on minimum quantity lubrication (MQL) coolant system for machining operations." International Journal of Current Engineering International Journal of Current Engineering and Technology 6, no. 5 (2016): 1745-1751.

[8] Walker, T. "MQL handbook: a guide to machining with minimum quantity lubrication." Unist, Inc. (2013).

[9] Li, Changhe, Huayang Zhao, Dongzhou Jia, Dongkun Zhang, and Yali Hou. "Experimental study on generation mechanism and influencing factors of metal machining fluid oil mist microparticles." International Journal of Control and Automation 7, no. 7 (2014): 423-438. https://doi.org/10.14257/ijca.2014.7.7.35

[10] Najiha, M. S., M. M. Rahman, and K. Kadirgama. "Minimum quantity lubrication: Quantifying non-deterministic component of sustainability index for machining operations." International Journal of Automotive \& Mechanical Engineering 13, no. 1 (2016): 3190-3200. https://doi.org/10.15282/ijame.13.1.2016.6.0266

[11] Najiha, M. S., M. M. Rahman, M. Kamal, A. R. Yusoff, and K. Kadirgama. "Minimum quantity lubricant flow analysis in end milling processes: A computational fluid dynamics approach." Journal of Mechanical Engineering and Sciences 3 (2012): 340-345. https://doi.org/10.15282/jmes.3.2012.10.0032

[12] Pusavec, Franci, Davorin Kramar, Peter Krajnik, and Janez Kopac. "Transitioning to sustainable production-part II: evaluation of sustainable machining technologies." Journal of Cleaner Production 18, no. 12 (2010): 1211-1221. https://doi.org/10.1016/i.jclepro.2010.01.015

[13] DeVries, M. F., and S. F. Murray. "Tribology at the cutting edge: cutting and grinding fluids." In Tribology symposium1994. New York: American Society of Mechanical Engineers, pp. 23-33. 1994.

[14] Banerjee, Nilanjan, and Abhay Sharma. "Identification of a friction model for minimum quantity lubrication machining." Journal of Cleaner Production 83 (2014): 437-443. https://doi.org/10.1016/i.jclepro.2014.07.034

[15] Ismail, Nur Izzati Khoirunnisa, Nurrina Rosli, Ahmad Razlan Yusoff, and Kenji Amagai. "Measurement of Liquid Film Thickness Accumulated on Surface Machined by Minimum Quantity Lubrication (MQL)." Journal of Advanced Research in Fluid Mechanics and Thermal Sciences 58, no. 1 (2019): 118-125.

[16] Safiei, Wahaizad, Md Mustafizur Rahman, Ahmad Razlan Yusoff, Wajiha Tasnim, and Zetty Akhtar Abd Malek. "Evaluation Of Cutting Force in End Milling Process of Aluminum Alloy 6061-T6 Using Tungsten Carbide Inserts with MQL Method Utilizing Hybrid Nanofluid." Journal of Advanced Research in Fluid Mechanics and Thermal Sciences 84, no. 1 (2021): 111-125. https://doi.org/10.37934/arfmts.84.1.111125

[17] Weinert, Klaus, Ichiro Inasaki, J. W. Sutherland, and Toshiaki Wakabayashi. "Dry machining and minimum quantity lubrication." CIRP Annals 53, no. 2 (2004): 511-537. https://doi.org/10.1016/S0007-8506(07)60027-4

[18] Diniz, Anselmo Eduardo, and Ricardo Micaroni. "Cutting conditions for finish turning process aiming: the use of dry cutting." International Journal of Machine Tools and Manufacture 42, no. 8 (2002): 899-904. https://doi.org/10.1016/S0890-6955(02)00028-7

[19] Sreejith, P. S., and B. K. A. Ngoi. "Dry machining: machining of the future." Journal of Materials Processing Technology 101, no. 1-3 (2000): 287-291. https://doi.org/10.1016/S0924-0136(00)00445-3 
[20] Varadarajan, A. S., P. K. Philip, and B. Ramamoorthy. "Investigations on hard turning with minimal pulsed jet of cutting fluid." In Proceedings of the International seminar on Manufacturing Technology Beyond, pp. 173-179. 2000.

[21] Attanasio, Aldo, Marcello Gelfi, Claudio Giardini, and Carlo Remino. "Minimal quantity lubrication in turning: Effect on tool wear." Wear 260, no. 3 (2006): 333-338. https://doi.org/10.1016/i.wear.2005.04.024

[22] Li, Kuan-Ming, and Cheng-Peng Lin. "Study on minimum quantity lubrication in micro-grinding." The International Journal of Advanced Manufacturing Technology 62, no. 1-4 (2012): 99-105. https://doi.org/10.1007/s00170-0113789-1

[23] Hadad, Mohammadjafar, and Banafsheh Sadeghi. "Minimum quantity lubrication-MQL turning of AISI 4140 steel alloy." Journal of Cleaner Production 54 (2013): 332-343. https://doi.org/10.1016/i.jclepro.2013.05.011

[24] Nam, Jung Soo, Pil-Ho Lee, and Sang Won Lee. "Experimental characterization of micro-drilling process using nanofluid minimum quantity lubrication." International Journal of Machine Tools and Manufacture 51, no. 7-8 (2011): 649-652. https://doi.org/10.1016/i.ijmachtools.2011.04.005

[25] Shen, Bin, Ajay P. Malshe, Parash Kalita, and Albert J. Shih. "Performance of novel MoS2 nanoparticles based grinding fluids in minimum quantity lubrication grinding." Transactions of Namri/SME 36, no. 357 (2008): $357-364$.

[26] Urmi, Wajiha Tasnim, A. S. Shafiqah, Md Mustafizur Rahman, Kumaran Kadirgama, and Md Abdul Maleque. "Preparation Methods and Challenges of Hybrid Nanofluids: A Review." Journal of Advanced Research in Fluid Mechanics and Thermal Sciences 78, no. 2 (2020): 56-66. https://doi.org/10.37934/arfmts.78.2.5666

[27] Urmi, WajihaTasnim, M. M. Rahman, and W. A. W. Hamzah. "An experimental investigation on the thermophysical properties of $40 \%$ ethylene glycol based $\mathrm{TiO}_{2}-\mathrm{Al}_{2} \mathrm{O}_{3}$ hybrid nanofluids." International Communications in Heat and Mass Transfer 116 (2020): 104663. https://doi.org/10.1016/j.icheatmasstransfer.2020.104663

[28] Urmi, Wajiha Tasnim, M. M. Rahman, K. Kadirgama, D. Ramasamy, and M. A. Maleque. "An overview on synthesis, stability, opportunities and challenges of nanofluids." Materials Today: Proceedings 41, no. 1 (2021): 30-37. https://doi.org/10.1016/i.matpr.2020.10.998

[29] Shen, Bin, Albert J. Shih, and Simon C. Tung. "Application of nanofluids in minimum quantity lubrication grinding." Tribology Transactions 51, no. 6 (2008): 730-737. https://doi.org/10.1080/10402000802071277

[30] Kamata, Yasuhiro, and Toshiyuki Obikawa. "High speed MQL finish-turning of Inconel 718 with different coated tools." Journal of Materials Processing Technology $192 \quad$ (2007): $281-286$. https://doi.org/10.1016/i.jmatprotec.2007.04.052

[31] Shokoohi, Yousef, Ehsan Khosrojerdi, and BH Rassolian Shiadhi. "Machining and ecological effects of a new developed cutting fluid in combination with different cooling techniques on turning operation." Journal of Cleaner Production 94 (2015): 330-339. https://doi.org/10.1016/j.jclepro.2015.01.055

[32] Das, Rabin Kumar, Ashok Kumar Sahoo, Purna Chandra Mishra, Ramanuj Kumar, and Amlana Panda. "Comparative machinability performance of heat treated 4340 Steel under dry and minimum quantity lubrication surroundings." Procedia Manufacturing 20 (2018): 377-385. https://doi.org/10.1016/i.promfg.2018.02.055

[33] Patole, P. B., and V. V. Kulkarni. "Optimization of process parameters based on surface roughness and cutting force in MQL turning of AISI 4340 using nano fluid." Materials Today: Proceedings 5, no. 1 (2018): $104-112$. https://doi.org/10.1016/i.matpr.2017.11.060

[34] Ekinovic, S., H. Prcanovic, and E. Begovic. "Investigation of influence of MQL machining parameters on cutting forces during MQL turning of carbon steel St52-3." Procedia Engineering 132 (2015): 608-614. https://doi.org/10.1016/i.proeng.2015.12.538

[35] Joshi, Kamal Kishore, Ramanuj Kumar, and Anurag. "An experimental investigations in turning of Incoloy 800 in dry, MQL and flood cooling conditions." Procedia Manufacturing $20 \quad$ (2018): $350-357$. https://doi.org/10.1016/i.promfg.2018.02.051

[36] Vishnu, A. Venkata, P. Jamaleswara Kumar, and M. Venkata Ramana. "Comparison among Dry, Flooded and MQL Conditions in Machining of EN 353 Steel Alloys-An Experimental Investigation." Materials Today: Proceedings 5, no. 11 (2018): 24954-24962. https://doi.org/10.1016/i.matpr.2018.10.296

[37] Das, Rabin Kumar, Ramanuj Kumar, Gourab Sarkar, Saibal Sahoo, Ashok Kumar Sahoo, and Purna Chandra Mishra. "Comparative machining performance of hardened AISI 4340 Steel under dry and minimum quantity lubrication environments." Materials Today: Proceedings 5, no. $11 \quad$ (2018): 24898-24906. https://doi.org/10.1016/i.matpr.2018.10.289

[38] Sreejith, P. S. "Machining of 6061 aluminium alloy with MQL, dry and flooded lubricant conditions." Materials Letters 62, no. 2 (2008): 276-278. https://doi.org/10.1016/i.matlet.2007.05.019

[39] Sivaiah, P., and D. Chakradhar. "Effect of cryogenic coolant on turning performance characteristics during machining of 17-4 PH stainless steel: A comparison with MQL, wet, dry machining." CIRP Journal of Manufacturing Science and Technology 21 (2018): 86-96. https://doi.org/10.1016/i.cirpj.2018.02.004

[40] Marques, Armando, Mauro Paipa Suarez, Wisley Falco Sales, and Álisson Rocha Machado. "Turning of Inconel 718 with whisker-reinforced ceramic tools applying vegetable-based cutting fluid mixed with solid lubricants by MQL." 
$\begin{array}{lllllll}\text { Journal of } \quad \text { Materials } & \text { Processing } & \text { Technology } & 266 & \text { (2019): } & 530-543 .\end{array}$

https://doi.org/10.1016/i.jmatprotec.2018.11.032

[41] Abd Rahim, Erween, and Hemarani Dorairaju. "Evaluation of mist flow characteristic and performance in minimum quantity lubrication (MQL) machining." $\quad$ Measurement $123 \quad$ (2018): $213-225$. https://doi.org/10.1016/j.measurement.2018.03.015

[42] Mia, Mozammel, Asaduzzaman Rifat, Md Farhan Tanvir, Munish Kumar Gupta, Md Jubayer Hossain, and Anjan Goswami. "Multi-objective optimization of chip-tool interaction parameters using Grey-Taguchi method in MQLassisted turning." Measurement 129 (2018): 156-166. https://doi.org/10.1016/i.measurement.2018.07.014

[43] Behera, B. C., S. Ghosh, and P. V. Rao. "Wear behavior of PVD TiN coated carbide inserts during machining of Nimonic 90 and Ti6Al4V superalloys under dry and MQL conditions." Ceramics International 42, no. 13 (2016): 14873-14885. https://doi.org/10.1016/j.ceramint.2016.06.124

[44] Biermann, D., and I. lovkov. "Investigations on the thermal workpiece distortion in MQL deep hole drilling of an aluminium cast alloy." CIRP Annals 64, no. 1 (2015): 85-88. https://doi.org/10.1016/i.cirp.2015.04.072

[45] Berzosa, F., B. De Agustina, and E. M. Rubio. "Tool selection in drilling of magnesium UNSM11917 pieces under dry and MQL conditions based on surface roughness." Procedia Engineering 184 (2017): $117-127$. https://doi.org/10.1016/i.proeng.2017.04.076

[46] Kuzu, Ali T., Wenwu Wu, David A. Stephenson, Mustafa Bakkal, Jun Hong, and Albert J. Shih. "High-throughput dry and minimum quantity lubrication drilling of compacted graphite iron." Procedia CIRP 46 (2016): 87-90. https://doi.org/10.1016/i.procir.2016.03.191

[47] Bhowmick, S., M. J. Lukitsch, and A. T. Alpas. "Tapping of Al-Si alloys with diamond-like carbon coated tools and minimum quantity lubrication." Journal of Materials Processing Technology 210, no. 15 (2010): 2142-2153. https://doi.org/10.1016/i.jmatprotec.2010.07.032

[48] Heinemann, R., S. Hinduja, G. Barrow, and G. Petuelli. "Effect of MQL on the tool life of small twist drills in deephole drilling." International Journal of Machine Tools and Manufacture 46, no. 1 (2006): 1-6. https://doi.org/10.1016/j.ijmachtools.2005.04.003

[49] Le Coz, Gael, M. Marinescu, A. Devillez, D. Dudzinski, and Laurent Velnom. "Measuring temperature of rotating cutting tools: Application to MQL drilling and dry milling of aerospace alloys." Applied Thermal Engineering 36 (2012): 434-441. https://doi.org/10.1016/i.applthermaleng.2011.10.060

[50] Tasdelen, Bulent, T. Wikblom, and Sven Ekered. "Studies on minimum quantity lubrication (MQL) and air cooling at drilling." Journal of Materials Processing Technology 200, no. 1-3 (2008): 339-346. https://doi.org/10.1016/j.jmatprotec.2007.09.064

[51] Niketh, S., and G. L. Samuel. "Drilling performance of micro textured tools under dry, wet and MQL condition." Journal of Manufacturing Processes 32 (2018): 254-268. https://doi.org/10.1016/j.jmapro.2018.02.012

[52] Girinon, Mathieu, Habib Karaouni, Ugo Masciantonio, Fabien Lefebvre, Erwan Jourden, Frédéric Valiorgue, Joël Rech, and Eric Feulvarch. "Risks related to the lack of lubrication on surface integrity in drilling." Heliyon 5, no. 1 (2019): e01138. https://doi.org/10.1016/j.heliyon.2019.e01138

[53] Amini, Saeid, Iman Alinaghian, Mohammad Lotfi, Reza Teimouri, and Mahnoush Alinaghian. "Modified drilling process of AISI 1045 steel: a hybrid optimization." Engineering Science and Technology, an International Journal 20, no. 6 (2017): 1653-1661. https://doi.org/10.1016/j.jestch.2017.11.005

[54] Bhowmick, Sukanta, and Ahmet T. Alpas. "Minimum quantity lubrication drilling of aluminium-silicon alloys in water using diamond-like carbon coated drills." International Journal of Machine Tools and Manufacture 48, no. 12-13 (2008): 1429-1443. https://doi.org/10.1016/i.ijmachtools.2008.04.010

[55] Bhowmick, S., and A. T. Alpas. "The role of diamond-like carbon coated drills on minimum quantity lubrication drilling of magnesium alloys." Surface and Coatings Technology 205, no. 23-24 (2011): 5302-5311. https://doi.org/10.1016/i.surfcoat.2011.05.037

[56] Giasin, Khaled, and Sabino Ayvar-Soberanis. "Microstructural investigation of drilling induced damage in fibre metal laminates constituents." Composites Part A: Applied Science and Manufacturing 97 (2017): 166-178. https://doi.org/10.1016/j.compositesa.2017.02.024

[57] Biermann, Dirk, and Ivan lovkov. "Modeling and simulation of heat input in deep-hole drilling with twist drills and MQL." Procedia CIRP 8 (2013): 88-93. https://doi.org/10.1016/i.procir.2013.06.070

[58] Kuzu, A. T., K. Rahimzadeh Berenji, B. C. Ekim, and Mustafa Bakkal. "The thermal modeling of deep-hole drilling process under MQL condition." Journal of Manufacturing Processes 29 (2017): $194-203$. https://doi.org/10.1016/i.jmapro.2017.07.020

[59] Chatha, Sukhpal Singh, Amrit Pal, and Tarjeet Singh. "Performance evaluation of aluminium 6063 drilling under the influence of nanofluid minimum quantity lubrication." Journal of Cleaner Production 137 (2016): 537-545. https://doi.org/10.1016/j.jclepro.2016.07.139 
[60] Bhowmick, Sukanta, Michael J. Lukitsch, and Ahmet T. Alpas. "Dry and minimum quantity lubrication drilling of cast magnesium alloy (AM60)." International Journal of Machine Tools and Manufacture 50, no. 5 (2010): $444-457$. https://doi.org/10.1016/j.ijmachtools.2010.02.001

[61] Bandapalli, Chakradhar, Bharatkumar Mohanbhai Sutaria, Dhananjay Vishnu Prasad Bhatt, and Kundan Kumar Singh. "Tool wear analysis of micro end mills-uncoated and PVD coated TiAIN \& AITiN in high speed micro milling of titanium alloy-Ti-0.3 Mo-0.8 Ni." Procedia CIRP 77 (2018): 626-629. https://doi.org/10.1016/i.procir.2018.08.191

[62] Rahmati, Bizhan, Ahmed AD Sarhan, and M. Sayuti. "Morphology of surface generated by end milling AL6061-T6 using molybdenum disulfide $\left(\mathrm{MoS}_{2}\right)$ nanolubrication in end milling machining." Journal of Cleaner Production 66 (2014): 685-691. https://doi.org/10.1016/i.jclepro.2013.10.048

[63] Sharif, S., M. A. Hisyam, D. Kurniawan, and E. A. Orady. "Performance evaluation of vegetable oil as an alternative cutting lubricant when end milling stainless steel using TiAIN coated carbide tools." Transactions of NAMRI/SME 37 (2009): 9-14.

[64] Uysal, Alper, Furkan Demiren, and Erhan Altan. "Applying minimum quantity lubrication (MQL) method on milling of martensitic stainless steel by using nano $\mathrm{MoS}_{2}$ reinforced vegetable cutting fluid." Procedia-Social and Behavioral Sciences 195 (2015): 2742-2747. https://doi.org/10.1016/i.sbspro.2015.06.384

[65] Urmi, Wajiha Tasnim, Md Mustafizur Rahman, Wan Azmi Wan Hamzah, Kumaran Kadirgama, Devarajan Ramasamy, and Md Abdul Maleque. "Experimental Investigation on the Stability of 40\% Ethylene Glycol Based TiO2-Al2O3 Hybrid Nanofluids." Journal of Advanced Research in Fluid Mechanics and thermal Sciences 69, no. 1 (2020): 110121. https://doi.org/10.37934/arfmts.69.1.110121

[66] Wang, Chengdong, Kang Li, Ming Chen, and Zhiqiang Liu. "Evaluation of minimum quantity lubrication effects by cutting force signals in face milling of Inconel 182 overlays." Journal of Cleaner Production 108 (2015): 145-157. https://doi.org/10.1016/i.jclepro.2015.06.095

[67] Kim, Seong Hoon, Sang Won Lee, Sangmok Han, and Sung-Min Kim. "Numerical investigation of thermal characteristics of spray cooling with minimum quantity lubrication in milling process." Applied Mathematical Modelling 65 (2019): 137-147. https://doi.org/10.1016/i.apm.2018.08.011

[68] Mia, Mozammel. "Mathematical modeling and optimization of MQL assisted end milling characteristics based on RSM and Taguchi method." https://doi.org/10.1016/i.measurement.2018.02.017

[69] Pereira, Octavio, P. Català, Adrián Rodríguez, Txomin Ostra, J. Vivancos, Asunción Rivero, and Luís Norberto Lópezde-Lacalle. "The use of hybrid CO2+ MQL in machining operations." Procedia Engineering 132 (2015): $492-499$. https://doi.org/10.1016/j.proeng.2015.12.524

[70] Tunc, Lutfi Taner, Yuchen Gu, and Mary Grace Burke. "Effects of minimal quantity lubrication (MQL) on surface integrity in robotic milling of austenitic stainless steel." Procedia CIRP 45 (2016): 215-218. https://doi.org/10.1016/i.procir.2016.02.337

[71] Kedare, S. B., D. R. Borse, and P. T. Shahane. "Effect of minimum quantity lubrication (MQL) on surface roughness of mild steel of 15HRC on universal milling machine." Procedia Materials Science 6 (2014): $150-153$. https://doi.org/10.1016/j.mspro.2014.07.018

[72] Iskandar, Y., Amit Tendolkar, M. H. Attia, Patrick Hendrick, Ahmed Damir, and Christophe Diakodimitris. "Flow visualization and characterization for optimized MQL machining of composites." CIRP Annals 63, no. 1 (2014): 7780. https://doi.org/10.1016/i.cirp.2014.03.078

[73] Liao, Y. S., H. M. Lin, and Y. C. Chen. "Feasibility study of the minimum quantity lubrication in high-speed end milling of NAK80 hardened steel by coated carbide tool." International Journal of Machine Tools and Manufacture 47, no. 11 (2007): 1667-1676. https://doi.org/10.1016/i.ijmachtools.2007.01.005

[74] Kumar, SP Leo. "Experimental investigations and empirical modeling for optimization of surface roughness and machining time parameters in micro end milling using Genetic Algorithm." Measurement 124 (2018): 386-394. https://doi.org/10.1016/i.measurement.2018.04.056

[75] MaClure, T. F., R. Adams, and M. D. Gugger. "Comparison of flood vs. microlubrication on machining performance." Unist, 2001. http://www.unist.com/techsolve.html.

[76] Tawakoli, T., M. J. Hadad, M. H. Sadeghi, A. Daneshi, S. Stöckert, and A. Rasifard. "An experimental investigation of the effects of workpiece and grinding parameters on minimum quantity lubrication-MQL grinding." International Journal of Machine Tools and Manufacture 49, no. 12-13 (2009): 924-932. https://doi.org/10.1016/i.ijmachtools.2009.06.015

[77] Rabiei, F., A. R. Rahimi, M. J. Hadad, and M. Ashrafijou. "Performance improvement of minimum quantity lubrication (MQL) technique in surface grinding by modeling and optimization." Journal of Cleaner Production 86 (2015): 447-460. https://doi.org/10.1016/i.jclepro.2014.08.045 
[78] Barczak, L. M., A. D. L. Batako, and M. N. Morgan. "A study of plane surface grinding under minimum quantity lubrication (MQL) conditions." International Journal of Machine Tools and Manufacture 50, no. 11 (2010): $977-985$. https://doi.org/10.1016/j.ijmachtools.2010.07.005

[79] Safiei, W., M. M. Rahman, A. R. Yusoff, M. N. Arifin, and W. Tasnim. "Effects of $\mathrm{SiO}_{2}-\mathrm{Al}_{2} \mathrm{O}_{3}-\mathrm{ZrO} 2$ Tri-hybrid Nanofluids on Surface Roughness and Cutting Temperature in End Milling Process of Aluminum Alloy 6061-T6 Using Uncoated and Coated Cutting Inserts with Minimal Quantity Lubricant Method." Arabian Journal for Science and Engineering 46 (2021): 7699-7718. https://doi.org/10.1007/s13369-021-05533-7 